\title{
Hyperbaric oxygen increases glioma cell sensitivity to antitumor treatment with a novel isothiourea derivative in vitro
}

\author{
KATARZYNA ZEMBRZUSKA, ROBERT P. OSTROWSKI and EWA MATYJA \\ Department of Experimental and Clinical Neuropathology, Mossakowski Medical Research Centre, \\ Polish Academy of Sciences, 02-106 Warsaw, Poland
}

Received October 26, 2018; Accepted March 4, 2019

DOI: $10.3892 /$ or.2019.7064

\begin{abstract}
Glioblastoma (GBM) is the most common primary brain tumor. Tumor hypoxia is a pivotal factor responsible for the progression of this malignant glioma, and its resistance to radiation and chemotherapy. Thus, improved tumor tissue oxygenation may promote greater sensitivity to anticancer treatment. Protein kinase D1 (PKD1) protects cells from oxidative stress, and its abnormal activity serves an important role in multiple malignancies. The present study examined the effects of various oxygen conditions on the cytotoxic potential of the novel isothiourea derivate N,N'-dimethyl-S-(2,3,4,5,6-pentabromobenzyl)isothiouronium bromide (ZKK-3) against the T98G GBM cell line. ZKK-3 was applied at concentrations of 10,25 and $50 \mu \mathrm{M}$, and cells were maintained under conditions of normoxia, anoxia, hypoxia, hyperbaric oxygen (HBO), hypoxia/hypoxia and hypoxia/HBO. The proliferation and viability of neoplastic cells, and protein expression levels of hypoxia-inducible factor $1 \alpha(\mathrm{HIF}-1 \alpha)$, PKD1, phosphorylated (p)PKD1 (Ser 916) and pPKD1 (Ser 744/748) kinases were evaluated. Oxygen deficiency, particularly regarding hypoxia, could diminish the cytotoxic effect of ZKK-3 at 25 and $50 \mu \mathrm{M}$ and improve T98G cell survival compared with normoxia. HBO significantly reduced cell proliferation and increased $\mathrm{T} 98 \mathrm{G}$ cell sensitivity to ZKK-3 when compared with normoxia. HIF-1 $\alpha$ expression levels were increased under hypoxia compared with normoxia and decreased under HBO compared with hypoxia/hypoxia
\end{abstract}

Correspondence to: Professor Ewa Matyja, Department of Experimental and Clinical Neuropathology, Mossakowski Medical Research Centre, Polish Academy of Sciences, 5 Pawińskiego Street, 02-106 Warsaw, Poland

E-mail: ematyja@imdik.pan.pl

Abbreviations: GBM, glioblastoma; HBO, hyperbaric oxygen therapy; HIF-1 $\alpha$, hypoxia-inducible factor-1 $\alpha$; PKD1, protein kinase D1; T98G, human glioblastoma cell line; ZKKs, pentabromobenzyl-isothioureas; ZKK-3, N,N'-dimethyl-S-(2,3,4,5,6-pentabromobenzyl)-isothiouronium bromide

Key words: cancer, glioblastoma, hyperbaric oxygen therapy, hypoxia, isothiourea derivatives at 0,10 and $50 \mu \mathrm{M} \mathrm{ZKK-3,} \mathrm{suggesting} \mathrm{that} \mathrm{HBO}$ improved oxygenation of the cells. ZKK-3 exhibited inhibitory activity against pPKD1 (Ser 916) kinase; however, the examined oxygen conditions did not appear to significantly influence the expression of this phosphorylated form in cells treated with the tested compound. Regarding pPKD1 (Ser 744/748), a significant difference in expression was observed only for cells treated with $10 \mu \mathrm{M}$ ZKK-3 and hypoxia/hypoxia compared with normoxia. However, there were significant differences in the expression levels of both phosphorylated forms of PKD1 under different oxygen conditions in the controls. In conclusion, the combination of isothiourea derivatives and hyperbaric oxygenation appears to be a promising therapeutic approach for malignant glioma treatment.

\section{Introduction}

Glioblastoma (GBM) is the most common primary brain tumor (1). According to the World Health Organization classification, it is considered a grade IV malignancy, and its standard treatment entails surgery, radiotherapy and chemotherapy $(2,3)$. However, the diffusely infiltrative growth pattern of GBM typically prevents total surgical resection, resulting in rapid tumor recurrence (4). Despite improvements in diagnostic and therapeutic strategies, the clinical prognosis for patients with high-grade gliomas remains poor, with a typical median survival of $<16$ months (2). Temozolomide, a chemotherapeutic agent commonly used against gliomas, only extends patient survival by a few months $(2,5,6)$. Therefore, intensive research is now focused on the development of improved treatment strategies.

Tumor hypoxia is a pivotal factor involved in promoting GBM progression and its marked resistance to radiation and chemotherapy (7-9). An insufficient oxygen supply prompts a number of adverse metabolic changes and intensifies angiogenesis and apoptosis (10). These changes are predominantly regulated by hypoxia-inducible factor-1 (HIF-1), which comprises two subunits: $\alpha$ and $\beta(8,11,12)$. HIF- $1 \alpha$ expression strongly depends on the cell oxygenation level (13).

Hyperbaric oxygen (HBO) therapy improves neoplastic tissue oxygenation and inhibits HIF-1 $\alpha$ activity (14-16). Theoretically, improved oxygenated tumor tissue may become more susceptible to anticancer therapies. HBO is widely used as an adjunctive treatment for various pathological 
states, including inadequately healing wounds, decompression sickness and carbon monoxide poisoning (17). Previous studies have investigated its use in oncology in combination with radiotherapy, chemotherapy, photodynamic therapy and surgery $(10,14,16,18)$. Although some of these studies have reached the clinical trial phase, HBO is not yet widely applied in cancer treatment.

Tumor progression is commonly accompanied with the development of resistance mechanisms to medical treatment, which suggests more effective chemotherapeutic agents for innovative treatments are necessary (4). Heterocyclic isothiourea derivatives, also called pentabromobenzyl-isothioureas (ZKKs), are a novel promising group of cytotoxic compounds. Their proapoptotic and cytotoxic properties toward various tumor cells, including GBM, have been demonstrated in vitro $(19,20)$. ZKKs have a chemical structure similar to casein kinase 2 (CK2) inhibitors, including benzotriazoles (TBB) and benzimidazoles (TBI and DMAT) (21). However, ZKKs do not effectively inhibit CK2 activity. Studies using a wide panel of protein kinases have indicated that N,N'-dimethyl-S-(2,3,4,5,6-pentabromobenzyl)isothiouronium bromide (ZKK-3) specifically inhibits kinases other than CK2, including protein kinase D1 (PKD1) $(21,22)$. Notably, PKD1 mediates the detoxification of mitochondrial reactive oxygen and nitrogen species, protecting cells from oxidative stress (23). Disruption of PKD1 expression can promote the development of numerous pathological states, including neoplastic processes $(24,25)$.

In the present study, the effects of various oxygen conditions on the cytotoxic potential of ZKK-3 against the T98G GBM cell line were examined. Cells were maintained under conditions of normoxia, anoxia, hypoxia, hyperbaric oxygen (HBO), hypoxia/hypoxia, and hypoxia/HBO, and ZKK-3 was applied at concentrations of 10,25 and $50 \mu \mathrm{M}$. The cell proliferation and viability, and protein expression levels of HIF-1 $\alpha$, PKD1, phosphorylated (p)PKD1 (Ser 916) and pPKD1 (Ser 744/748) kinases were evaluated.

\section{Materials and methods}

Cell line. Experiments were conducted using the human GBM T98G cell line (American Type Culture Collection, Manassas, VA, USA). Cells were maintained at $37^{\circ} \mathrm{C}$ in an atmosphere containing $95 \%$ absolute humidity and $95 \%$ air $/ 5 \% \mathrm{CO}_{2}$ in minimum essential media (MEM; Sigma-Aldrich; Merck KGaA, Darmstadt, Germany) supplemented with $10 \%$ fetal bovine serum (Gibco; Thermo Fisher Scientific, Inc., Waltham, MA, USA), $1 \%$ penicillin/streptomycin solution (Gibco; Thermo Fisher Scientific, Inc.) and 1\% non-essential amino acid solution (Sigma-Aldrich; Merck KGaA, Darmstadt, Germany).

Examined compound and oxygen conditions. The modified isothiourea derivative ZKK-3 (Fig. 1) was synthesized by Professor Zygmunt Kazimierczuk according to a previously described procedure (20). The compound was dissolved in dimethyl sulfoxide (DMSO; AppliChem GmbH, Darmstadt, Germany) and added to the culture medium at concentrations of 10,25 and $50 \mu \mathrm{M}$. Control cultures were grown in standard conditions with DMSO but without ZKK-3 application $(0 \mu \mathrm{M})$.
Cells were cultured under different gas mixtures with varying oxygen contents as follows: Normoxia $\left(21 \% \mathrm{O}_{2} / 5 \% \mathrm{CO}_{2} / 74 \% \mathrm{~N}_{2}\right.$ was applied for $24 \mathrm{~h}$ post-ZKK-3 treatment), anoxia (5\% $\mathrm{CO}_{2} / 95 \% \mathrm{~N}_{2}$ was applied for $24 \mathrm{~h}$ post-ZKK-3 treatment); hypoxia $\left(\begin{array}{llll}1 \% & \mathrm{O}_{2} / 5 \% & \mathrm{CO}_{2} / 94 \% & \mathrm{~N}_{2}\end{array}\right.$ was applied for $24 \mathrm{~h}$ post-ZKK-3 treatment); $\mathrm{HBO}$ $\left(97.5 \% \mathrm{O}_{2} / 2.5 \% \mathrm{CO}_{2}\right.$ under pressure of 2 ATA was applied for $1 \mathrm{~h}$ post-ZKK-3 treatment, which was followed by $23 \mathrm{~h}$ of normoxia); hypoxia/hypoxia (double hypoxia; hypoxic gas $\left(1 \% \mathrm{O}_{2} / 5 \% \mathrm{CO}_{2} / 94 \% \mathrm{~N}_{2}\right)$ was applied for $24 \mathrm{~h}$ prior to ZKK-3 treatment, and then for an additional $24 \mathrm{~h}$ post-ZKK-3 treatment); and hypoxia/hyperbaric oxygen (hypoxia/HBO; hypoxia was applied for $24 \mathrm{~h}$ prior to ZKK-3 treatment, and HBO was applied post-ZKK-3 treatment). Anoxia and hypoxia experiments were performed in a Modular Incubator Chamber (MIC-101; Billups-Rothenberg, San Diego, CA, USA), whereas HBO experiments were conducted using a hyperbaric chamber (own design).

Cell proliferation rate assessment. T98G cells, seeded in dishes (6-cm diameter) at a density $1.2 \times 10^{5}$ cells/dish, were incubated using a HERAcell 150i $\mathrm{CO}_{2}$ Incubator (Thermo Fisher Scientific, Inc.) for $24 \mathrm{~h}$ with ZKK-3 at concentrations of 10,25 and $50 \mu \mathrm{M}$, at $37^{\circ} \mathrm{C}$ under various oxygen conditions, and the number of cells was subsequently determined. For this process, the medium was removed, and the cells were washed with phosphate-buffered saline (PBS), trypsinized with $0.05 \%$ Trypsin-EDTA (both from Gibco; Thermo Fisher Scientific, Inc.), and rotated for $10 \mathrm{~min}$ at $200 \mathrm{x}$ g at $4^{\circ} \mathrm{C}$ (Laboratory Centrifuge MPW-350R; MPW Med. Instruments, Warsaw, Poland). Following this, the pellet was suspended in $1 \mathrm{ml} \mathrm{MEM}$ and $4 \mathrm{ml}$ Coulter Isoton II Diluent (Beckman Coulter, Inc., Indianapolis, IN, USA). The cell numbers were counted using a Multisizer 3 cell counter (Beckman Coulter, Inc.). Control cells were grown under the examined oxygen conditions without ZKK-3. These investigations comprised at least six independent experiments with three repetitions in each $(n \geq 18)$. Pairwise comparisons of T98G cell proliferation under different oxygen conditions were performed as follows: Normoxia vs. anoxia, normoxia vs. hypoxia, normoxia vs. HBO and hypoxia vs. HBO.

Cell viability assay. T98G cells, seeded in 96-well plates at a density $5 \times 10^{3}$ cells/well, were incubated for 24 and $48 \mathrm{~h}$ with ZKK-3 at concentrations of 10,25 and $50 \mu \mathrm{M}$ at $37^{\circ} \mathrm{C}$ under various oxygen conditions and the viability was subsequently determined. In the $24 \mathrm{~h}$ examination, cells were treated with the CellTiter $96 \mathrm{AQ}_{\text {ueous }}$ One Solution Cell Proliferation Assay (Promega Corporation, Madison, WI, USA) and incubated at $37^{\circ} \mathrm{C}$ for $3 \mathrm{~h}$. The absorbance was measured at $490 \mathrm{~nm}$ using spectrophotometer (Epoch Microplate Reader; BioTek Instruments, Inc., Winooski, VT, USA). In the $48 \mathrm{~h}$ test, following the first $24 \mathrm{~h}$ incubation, the culture medium was replaced with fresh MEM containing ZKK-3, and cells were again incubated for $24 \mathrm{~h}$ at $37^{\circ} \mathrm{C}$ under the examined oxygen conditions. Following this, the viability was assessed using the CellTiter $96 \mathrm{AQ}_{\text {ueous }}$ One Solution Cell Proliferation Assay and spectrophotometer, as described above. Control groups included cells sustained under the examined oxygen conditions without ZKK-3. The study comprised at least five 
independent experiments with 10 repetitions in each $(n \geq 50)$. Pairwise comparisons of the viability of T98G cells under different oxygen conditions were performed as follows: Normoxia vs. anoxia, normoxia vs. hypoxia, normoxia vs. HBO and hypoxia vs. HBO.

Determination of HIF-1 $\alpha$ expression level. T98G cells were cultured with the examined compound under various oxygen conditions and lysed using the radioimmunoprecipitation assay lysis buffer system (Santa Cruz Biotechnology, Inc., Dallas, TX, USA) according to the protocol of the manufacturer. HIF-1 $\alpha$ expression was assessed by determining the HIF-1 $\alpha$ protein expression level in cell lysates using the HIF-1A ELISA kit (cat. no. EHIF1A5; Thermo Fisher Scientific Inc.) according to the protocol of the manufacturer. The total protein level in the cell lysates was evaluated using the Pierce BCA Protein Assay Kit (Thermo Fisher Scientific, Inc.) according to the protocol of the manufacturer.

Determination of the expression levels of PKDI and its phosphorylated forms. The expression levels of PKD1 and its phosphorylated forms were evaluated using western blot analysis. Cells were lysed using the RIPA Lysis Buffer System (Santa Cruz Biotechnology, Inc.) according to the protocol of the manufacturer, and the total protein level in the cell lysates was evaluated using the Pierce BCA Protein Assay Kit (Thermo Fisher Scientific, Inc.) according to the protocol of the manufacturer. Cell lysates, containing total protein, were mixed with Laemmli $2 X$ Concentrate Sample Buffer (Sigma-Aldrich; Merck KGaA) and loaded (20 $\mu \mathrm{g}$ total protein per lane) onto Mini-PROTEAN TGX Precast Gels (8-16\%; Bio-Rad Laboratories, Inc., Hercules, CA, USA). Following this, the proteins were electrotransferred onto nitrocellulose membranes (Bio-Rad Laboratories, Inc.). The membranes were washed in PBS, blocked for $1 \mathrm{~h}$ in non-fat $5 \%$ milk (for PKD1) or 5\% bovine serum albumin (Sigma-Aldrich; Merck KGaA) for phosphorylated forms of PKD1 at $4^{\circ} \mathrm{C}$, and subsequently incubated for $15 \mathrm{~h}$ at $4^{\circ} \mathrm{C}$ with primary antibodies against PKD/PKC $\mu$ (cat. no. 2052; 1:500 dilution; polyclonal, rabbit; Cell Signaling Technology, Inc., Danvers, MA, USA), Phospho-PKD/PKC $\mu$ (Ser 916) (cat. no. 2051; 1:1,000 dilution; polyclonal, rabbit; Cell Signaling Technology, Inc., Danvers, MA, USA), or Phospho-PKD/PKC $\mu$ (Ser 744/748) (cat. no. 2054; 1:1,000 dilution; polyclonal, rabbit; Cell Signaling Technology, Inc.). Following this, the membranes were washed three times in Tris-buffered saline with Tween-20 washing buffer and then twice in Tris-buffered saline washing buffer. The membranes were subsequently incubated at $37^{\circ} \mathrm{C}$ for $2 \mathrm{~h}$ with secondary anti-rabbit $\mathrm{IgG}$, horseradish peroxidase (HRP)-linked antibody (cat. no. 7074; 1:1,000 dilution; polyclonal, goat anti-rabbit; Cell Signaling Technology, Inc.). Protein bands were detected using Amersham ECL Prime Western Blotting Detection Reagent (GE Healthcare Life Sciences, Little Chalfont, UK), Carestream Medical X-ray film, Carestream Dental X-ray Developer and Carestream Dental X-ray Fixer (Carestream Dental; Carestream Health Inc., Rochester, NY, USA). Monoclonal anti- $\beta$-actin clone AC-15 (cat. no. A5441; 1:20,000 dilution; mouse; Sigma-Aldrich; Merck KGaA) and secondary chicken anti-mouse IgG-HRP (cat. no. sc-2954; 1:5,000 dilution; polyclonal; Santa Cruz

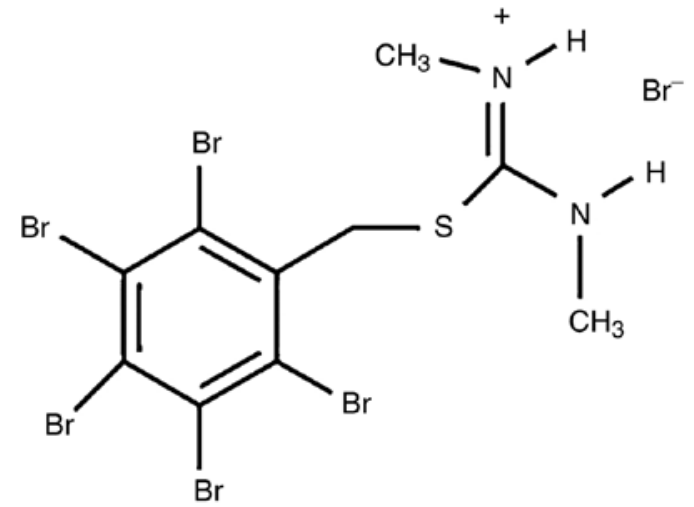

Figure 1. Structure of N,N'-dimethyl-S-(2,3,4,5,6-pentabromobenzyl)isothiouronium bromide.

Biotechnology, Inc.) were used as loading controls. The temperature and duration of incubation were the same as those indicated for primary and secondary antibodies indicated above, respectively. The grey value of the protein bands was determined using ImageJ 1.50i software (National Institutes of Health, Bethesda, MD, USA).

Statistical analysis. Statistical analysis of the data was performed using one-way analysis of variance and the Tukey's post hoc test. Results were expressed as the mean \pm standard error. $\mathrm{P}<0.05$ was considered to indicate a statistically significant difference.

\section{Results}

Cell proliferation rate. Application of 25 and $50 \mu \mathrm{M}$ ZKK-3 resulted in a markedly decreased numbers of cells compared with the controls under normoxia and anoxia, respectively (Fig. 2A). In cells without ZKK-3 or those treated with $10 \mu \mathrm{M}$ ZKK-3, markedly reduced proliferation under oxygen deprivation was indicated when compared with standard conditions. Statistical analysis revealed that the application of 25 and $50 \mu \mathrm{M}$ ZKK-3 significantly decreased cell proliferation by 41 and $80 \%$ under normoxia, and by 31 and $75 \%$ under anoxia, respectively, compared with the controls (Fig. 2B). Furthermore, anoxia alone or combined with $10 \mu \mathrm{M}$ ZKK-3 caused the number of living cells to significantly decrease by 18 and $15 \%$, respectively, relative to standard culture conditions. With 25 and $50 \mu \mathrm{M}$ ZKK-3 treatment, cell proliferation was similar under both oxygen conditions.

Under standard conditions, the number of cells markedly decreased with increasing ZKK-3 concentrations (Fig. 3A). However, under hypoxia, cell proliferation was not significantly changed under specific ZKK-3 concentrations. Statistical analysis revealed that the number of $\mathrm{T} 98 \mathrm{G}$ cells declined with increasing ZKK-3 concentrations under normoxic and hypoxic conditions when compared with the controls. Notably, this decrease was statistically significant for cells treated with 25 and $50 \mu \mathrm{M}$ ZKK-3 under normoxia (32 and 63\%, respectively) and hypoxia (20 and 48\%, respectively) compared with the controls. With $50 \mu \mathrm{M}$ ZKK-3, there were $40 \%$ more cells under hypoxia compared with cells under normoxia. With other ZKK-3 concentrations, no significant differences were 

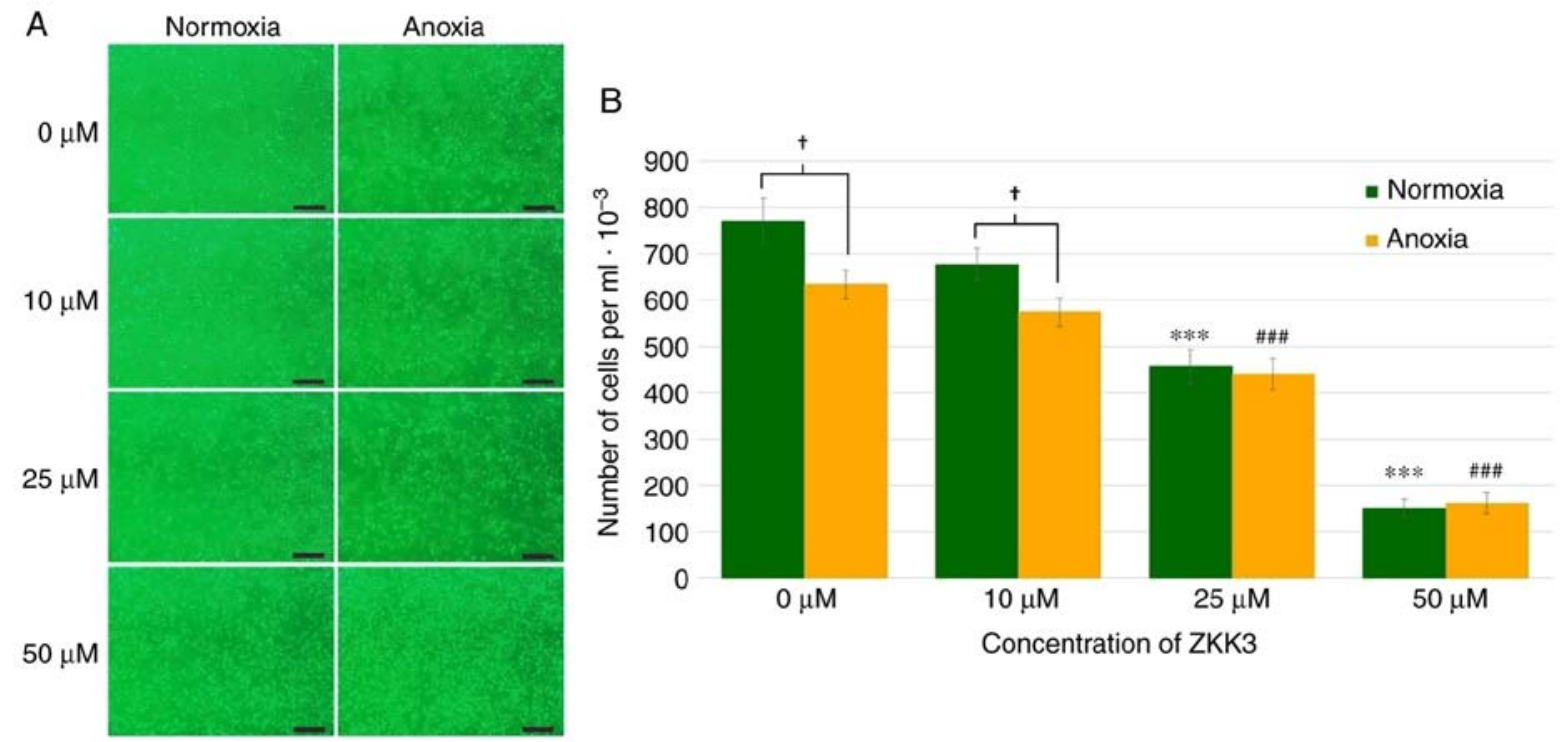

Figure 2. Growth of T98G cells following $24 \mathrm{~h}$ of incubation with ZKK-3 under normoxia or anoxia. (A and B) Influence of normoxia and anoxia on the proliferation of T98G cells following $24 \mathrm{~h}$ of incubation with ZKK-3. Scale bar=500 $\mu \mathrm{m}$. ${ }^{* * *} \mathrm{P}<0.001$ vs. control under normoxia; ${ }^{\# \# \#} \mathrm{P}<0.001 \mathrm{vs}$. control under anoxia; 'P $<0.05$ as indicated. ZKK-3, N,N'-dimethyl-S-(2,3,4,5,6-pentabromobenzyl)-isothiouronium bromide.

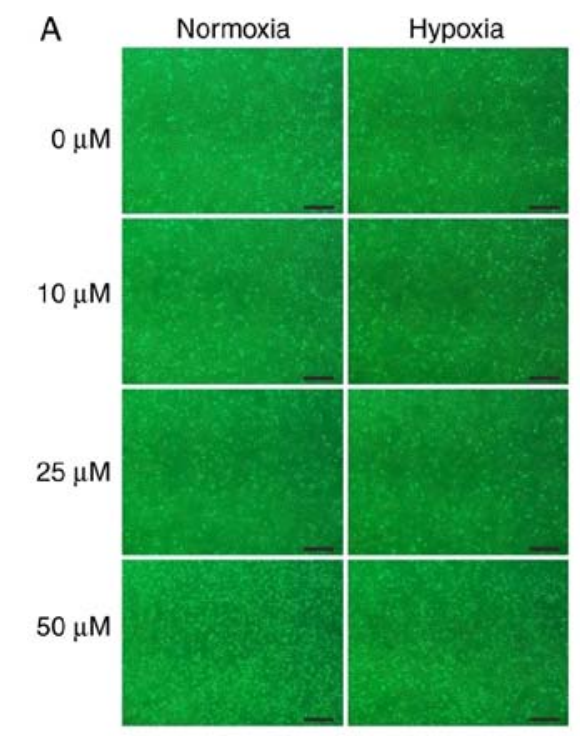

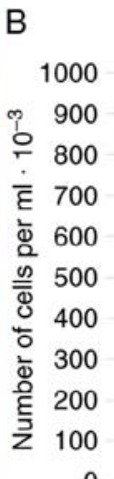

0

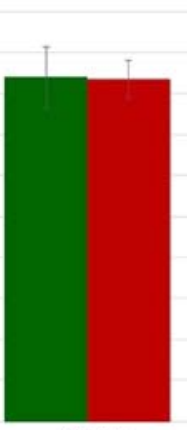

$0 \mu \mathrm{M}$

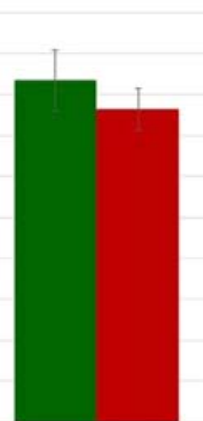

$10 \mu \mathrm{M}$

Concentration of ZKK3

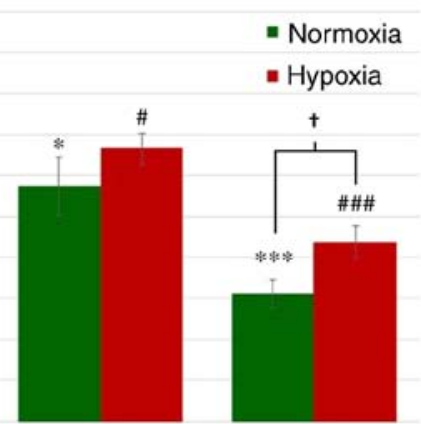

$50 \mu \mathrm{M}$

Figure 3. Growth of T98G cells following $24 \mathrm{~h}$ of incubation with ZKK-3 under normoxia or hypoxia. (A and B) Influence of normoxia and hypoxia on the proliferation of T98G cells following $24 \mathrm{~h}$ of incubation with ZKK-3. Scale bar $=500 \mu \mathrm{m}$. ${ }^{*} \mathrm{P}<0.05$ and ${ }^{* * *} \mathrm{P}<0.001$ vs. control under normoxia; ${ }^{\sharp} \mathrm{P}<0.05$ and

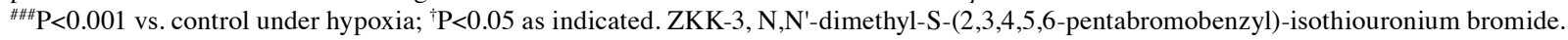

observed between the number of cells under hypoxia when compared with normoxia (Fig. 3B).

In control groups and groups treated with $10 \mu \mathrm{M}$ ZKK-3, similar numbers of GBM cells were observed under normoxia and $\mathrm{HBO}$ conditions (Fig. 4A). Incubation with 25 and $50 \mu \mathrm{M}$ ZKK-3 resulted in diminished proliferation compared with the respective controls, particularly following exposure to HBO. Statistical analysis of the proliferation assay results confirmed that application of 25 and $50 \mu \mathrm{M}$ ZKK-3 combined with $\mathrm{HBO}$ significantly reduced the number of GBM cells (Fig. 4B). Notably, under normoxia and HBO, respectively, treatment with $25 \mu \mathrm{M}$ ZKK-3 significantly reduced proliferation to 66 and $70 \%$ of control cells, while $50 \mu \mathrm{M}$ ZKK-3 significantly reduced proliferation to 33 and $20 \%$ of control cells. A statistically significant $45 \%$ difference in the extent of cell number reductions with $50 \mu \mathrm{M}$ ZKK-3 was identified between normoxia and $\mathrm{HBO}$ conditions.

Following incubation with 25 and $50 \mu \mathrm{M}$ ZKK-3, the number of morphologically intact $\mathrm{T} 98 \mathrm{G}$ cells was reduced under $\mathrm{HBO}$ compared with hypoxia (Fig. 5A). In control groups and cultures treated with $10 \mu \mathrm{M}$ ZKK-3, cell numbers were similar under hypoxic and $\mathrm{HBO}$ conditions. Statistical analysis revealed that treatment with 25 and $50 \mu \mathrm{M}$ ZKK-3 significantly reduced the number of neoplastic cells to 78 and $43 \%$ of control under hypoxia, and to 67 and $29 \%$ of control under HBO, respectively (Fig. 5B). For these ZKK-3 concentrations, the decrease in cell number was 10 and $30 \%$ greater, respectively, under HBO when compared with hypoxic conditions. 

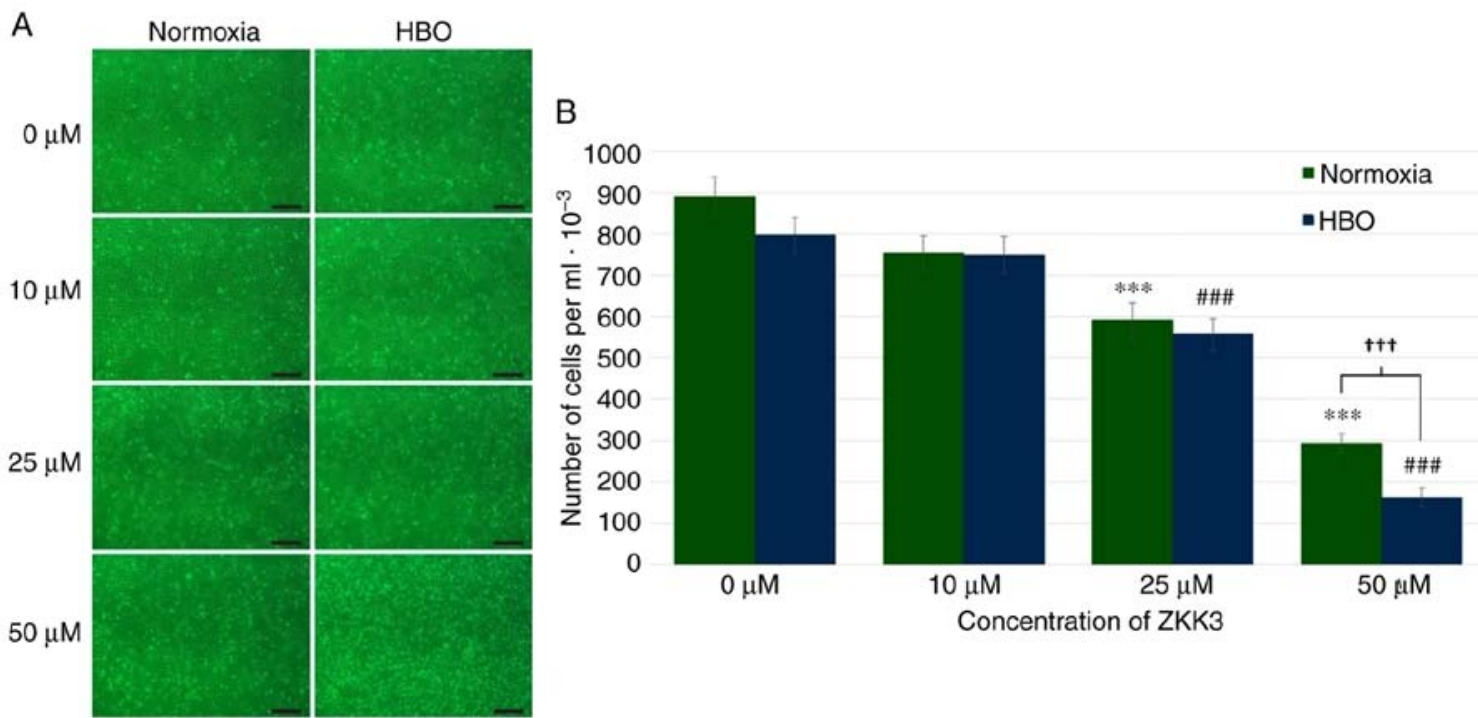

Figure 4. Growth of T98G cells following $24 \mathrm{~h}$ of incubation with ZKK-3 under normoxia or HBO. (A and B) Influence of normoxia and HBO on the proliferation of T98G cells following $24 \mathrm{~h}$ of incubation with $\mathrm{ZKK}-3$. Scale bar=500 $\mu \mathrm{m}$. ${ }^{* * *} \mathrm{P}<0.001$ vs. control under normoxia; ${ }^{\# \# \#} \mathrm{P}<0.001$ vs. control under $\mathrm{HBO}$;

${ }^{\dagger \dagger} \mathrm{P}<0.001$ as indicated. HBO, hyperbaric oxygen; ZKK-3, N,N'-dimethyl-S-(2,3,4,5,6-pentabromobenzyl)-isothiouronium bromide.
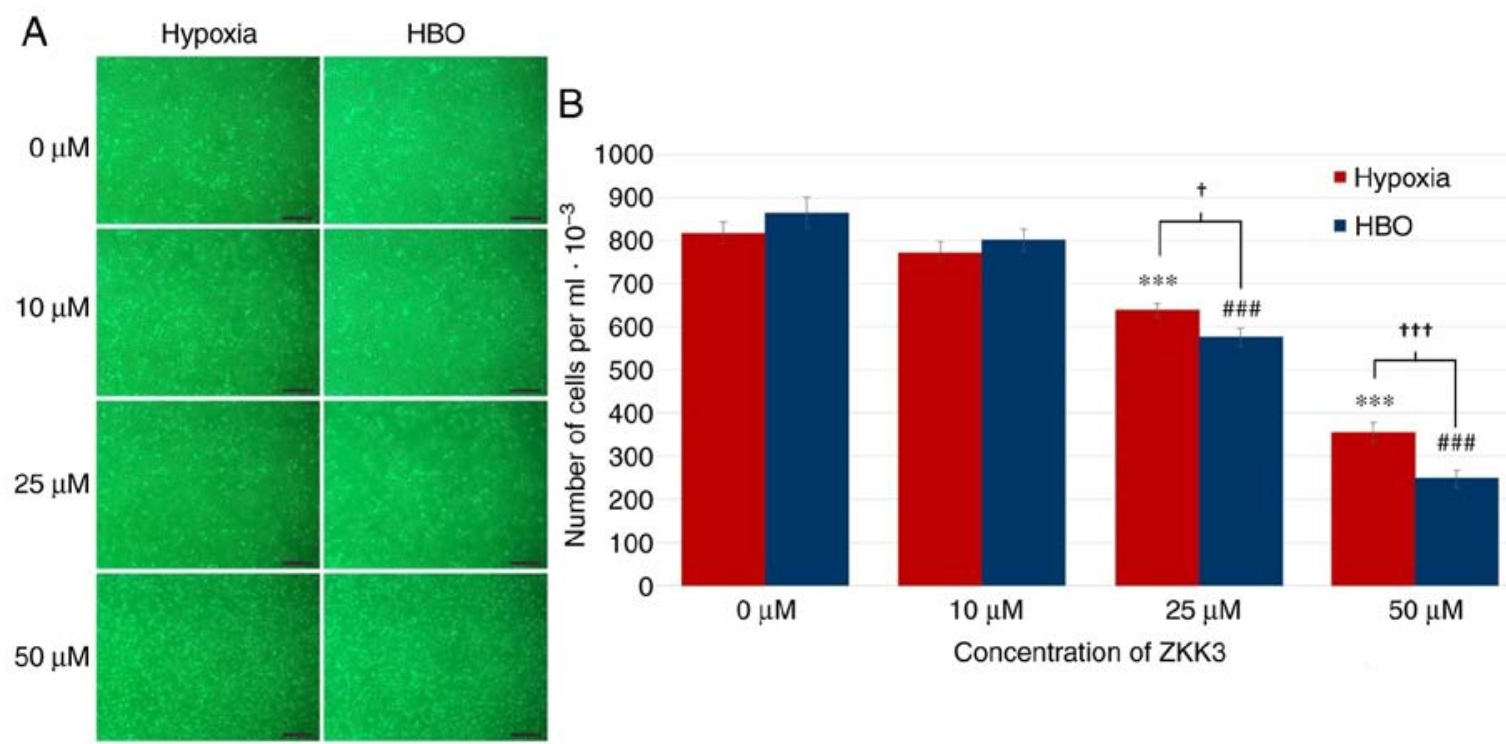

Figure 5. Growth of T98G cells following $24 \mathrm{~h}$ of incubation with ZKK-3 under hypoxia or HBO. (A and B) Influence of hypoxia and HBO on the proliferation of T98G cells following $24 \mathrm{~h}$ of incubation with ZKK-3. Scale bar $=500 \mu \mathrm{m}$. ${ }^{* * * *} \mathrm{P}<0.001$ vs. control under hypoxia; ${ }^{\# \# \#} \mathrm{P}<0.001$ vs. control under $\mathrm{HBO}$; ${ }^{\dagger} \mathrm{P}<0.05$ and ${ }^{\dagger \dagger} \mathrm{P}<0.001$ as indicated. HBO, hyperbaric oxygen; ZKK-3, N,N'-dimethyl-S-(2,3,4,5,6-pentabromobenzyl)-isothiouronium bromide.

Cell viability. GBM cell viability was significantly diminished following $24 \mathrm{~h}$ of incubation with 10,25 and $50 \mu \mathrm{M}$ of ZKK-3 under normoxia (by 32, 42 and 67\%, respectively) as well as under anoxia (by 36,57 , and $77 \%$, respectively) when compared with the controls (Fig. 6A). The number of living cells significantly differed between standard and anoxic conditions in control groups (increased by 101\%) and groups that were treated with 10 or $25 \mu \mathrm{M}$ ZKK-3 (increased by 90 and $50 \%$, respectively). In the $48 \mathrm{~h}$ experiment, 10, 25 and $50 \mu \mathrm{M}$ ZKK-3 treatment resulted in significantly decreased cell viability, with decreases of 49,71 and $83 \%$ under normoxia, and 61, 83 and 93\% under anoxia, respectively, when compared with the controls (Fig. 6B). However, the number of living cells was more than twice greater under anoxic conditions, alone or with $10 \mu \mathrm{M}$ ZKK-3 when compared with normoxia.

Following an incubation of $24 \mathrm{~h}$ under normoxic and hypoxic conditions, the number of T98G cells significantly decreased with 25 and $50 \mu \mathrm{M}$ ZKK-3 treatment (Fig. 7A). With 25 and $50 \mu \mathrm{M}$ ZKK-3 treatment, cell numbers were significantly reduced to 80 and $40 \%$ of vehicle control under standard conditions, and to 88 and $52 \%$ of vehicle control under hypoxia, respectively. In control groups, cell viability was significantly reduced under hypoxia compared with normoxia, whereas no significant differences were observed in cells with ZKK-3 supplementation under hypoxia compared with normoxia. Following $48 \mathrm{~h}$ of incubation, the cell viability under normoxia was significantly diminished following 

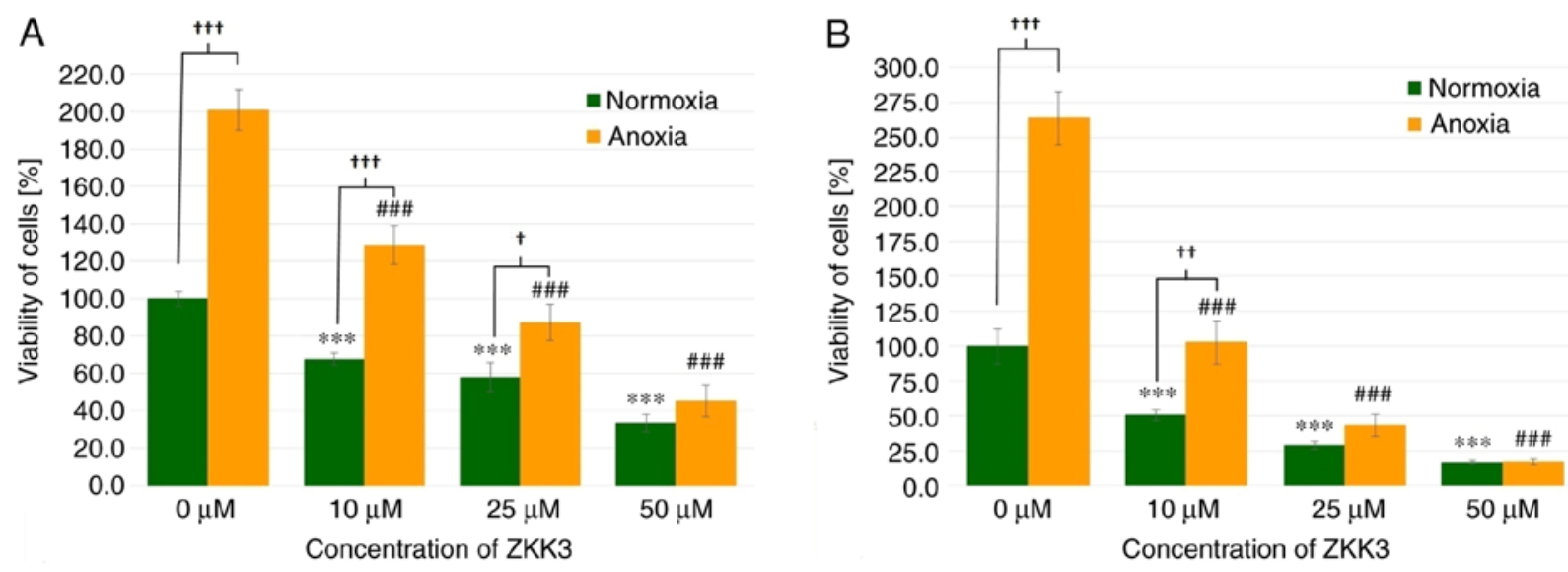

Figure 6. Viability of T98G cells treated with ZKK-3 under normoxia and anoxia. Influence of normoxia and anoxia on the viability of T98G cells following (A) $24 \mathrm{~h}$ and (B) $48 \mathrm{~h}$ of incubation with ZKK-3 ${ }^{* * * *} \mathrm{P}<0.001 \mathrm{vs}$. control under normoxia; ${ }^{\# \# \#} \mathrm{P}<0.001$ vs. control under anoxia; ${ }^{\dagger} \mathrm{P}<0.05$, ${ }^{\dagger} \mathrm{P}<0.01$ and ${ }^{\dagger \dagger \dagger} \mathrm{P}<0.001$ as indicated. ZKK-3, N,N'-dimethyl-S-(2,3,4,5,6-pentabromobenzyl)-isothiouronium bromide.
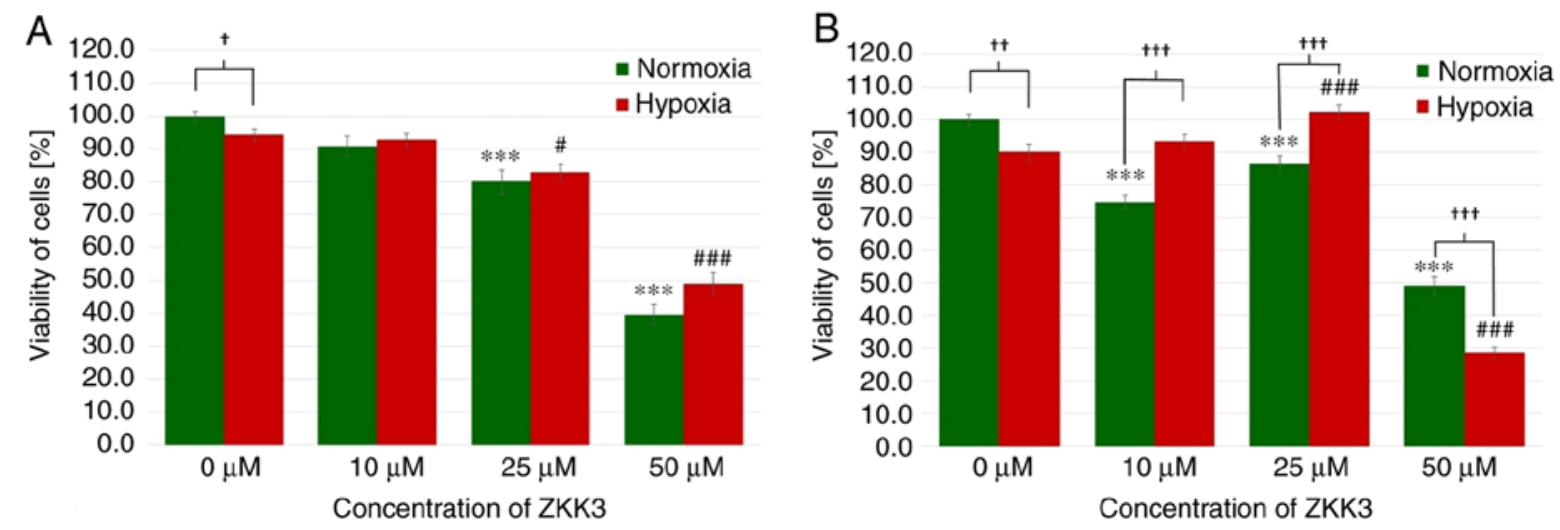

Figure 7. Viability of T98G cells treated with ZKK-3 under normoxia and hypoxia. Influence of normoxia and hypoxia on the viability of T98G cells following (A) $24 \mathrm{~h}$ and (B) $48 \mathrm{~h}$ of incubation with ZKK-3. ${ }^{* * *} \mathrm{P}<0.001 \mathrm{vs}$. control under normoxia; ${ }^{*} \mathrm{P}<0.05$ and ${ }^{\# \# \#} \mathrm{P}<0.001$ vs. control under hypoxia; ${ }^{\dagger} \mathrm{P}<0.05$, ${ }^{, t} \mathrm{P}<0.01$ and ${ }^{\dagger+} \mathrm{P}<0.001$ as indicated. ZKK-3, N,N'-dimethyl-S-(2,3,4,5,6-pentabromobenzyl)-isothiouronium bromide.

treatment with 10, 25 and $50 \mu \mathrm{M}$ ZKK-3 (by 25,13 and $51 \%$, respectively) when compared with the control, whereas cell viability under hypoxia was significantly decreased only when cells were treated with $50 \mu \mathrm{M}$ ZKK-3 (by $68 \%$ ) when compared with the control (Fig. 7B). Notably, under hypoxia the cell viability was significantly increased at $25 \mu \mathrm{M}$ ZKK-3 when compared with the respective control. Compared with normoxic conditions, the number of cells under hypoxia was significantly reduced by $10 \%$ without ZKK-3 application, and $41 \%$ reduced with application of $50 \mu \mathrm{M}$ ZKK-3. However, the number of cells under hypoxia was significantly elevated following application of 10 and $25 \mu \mathrm{M}$ ZKK-3 when compared with normoxia conditions.

Under normoxic and $\mathrm{HBO}$ conditions at $24 \mathrm{~h}, \mathrm{GBM}$ cell viability was significantly decreased with $25 \mu \mathrm{M}$ ZKK-3 treatment (by 19 and 24\%, respectively), as well as $50 \mu \mathrm{M}$ ZKK-3 treatment (40 and 71\%, respectively) compared with the controls (Fig. 8A). Furthermore, a statistically significant difference of $52 \%$ was observed between the decrease of the number of cells in normoxic compared with $\mathrm{HBO}$ conditions when using the highest ZKK-3 concentration. Extending the ZKK-3 exposure time to $48 \mathrm{~h}$ resulted in a significant reduction of cell viability to 80 and $58 \%$ of control under normoxia with 25 and $50 \mu \mathrm{M}$ ZKK-3, respectively, and to 82,68 and $37 \%$ of control under HBO with 10,25 , and $50 \mu \mathrm{M}$, respectively (Fig. 8B). The number of living cells was significantly reduced by 19 and $37 \%$ with 25 and $50 \mu \mathrm{M}$ ZKK-3, respectively, under $\mathrm{HBO}$ compared with normoxic conditions.

In the $24 \mathrm{~h}$ experiment, T98G cell viability was significantly decreased with 25 and $50 \mu \mathrm{M}$ ZKK-3 under hypoxia (decreases of 31 and $73 \%$, respectively), and with 10,25 and $50 \mu \mathrm{M}$ ZKK-3 under HBO (decreases of 21, 40 and 77\%, respectively) when compared with the controls. In the HBO group, the number of living cells was lower than that in the hypoxia group, with decreases of $19 \%$ in the control groups, and of 17 and $19 \%$ when cells were treated with 10 and $25 \mu \mathrm{M}$ ZKK-3, respectively. Similar alterations were observed in $48 \mathrm{~h}$ incubations with ZKK-3 (Fig. 9B). Under hypoxia, cell viability significantly decreased with 25 and $50 \mu \mathrm{M}$ ZKK-3 treatment (by 12 and 80\%, respectively) compared with the control. By contrast, under HBO conditions, the living cell number was significantly diminished following the application of 10, 25 and $50 \mu \mathrm{M}$ ZKK-3 (by 26, 18 and 79\%, respectively) compared with the control. Compared with hypoxia, cell viability under HBO conditions was diminished by 28 and $12 \%$ with 10 and $25 \mu \mathrm{M}$ ZKK-3. 

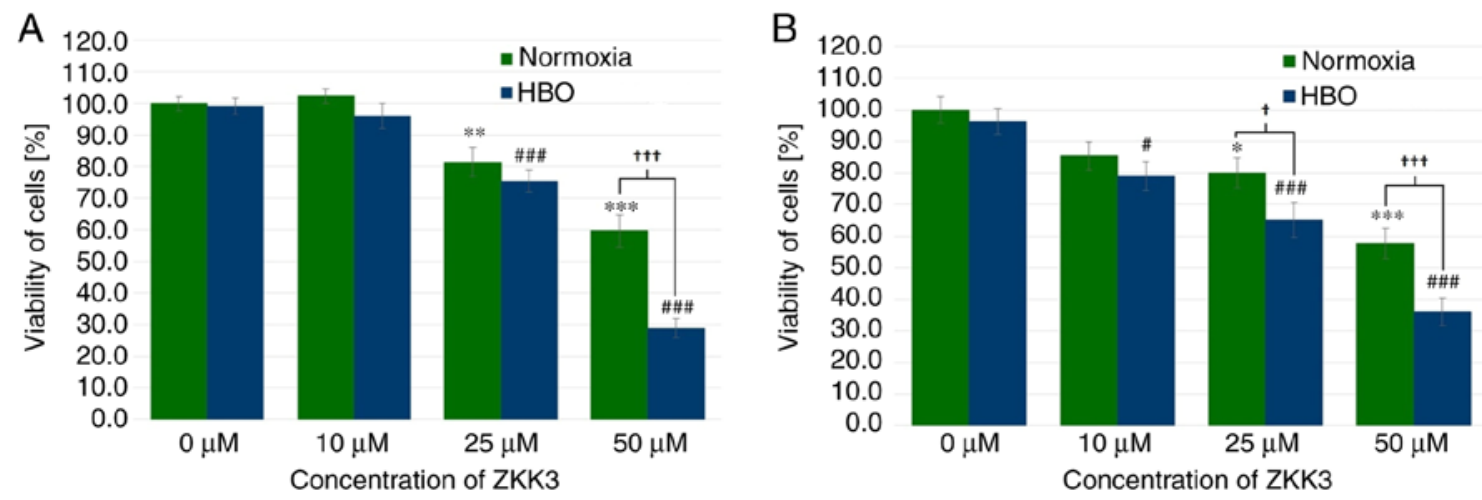

Figure 8. Viability of T98G cells treated with ZKK-3 under normoxia and HBO. Influence of normoxia and HBO on the viability of T98G cells following (A) $24 \mathrm{~h}$ and (B) $48 \mathrm{~h}$ of incubation with ZKK-3. ${ }^{*} \mathrm{P}<0.05,{ }^{* *} \mathrm{P}<0.01$ and ${ }^{* * *} \mathrm{P}<0.001$ vs. control under normoxia; ${ }^{\#} \mathrm{P}<0.05$ and ${ }^{\# \# t} \mathrm{P}<0.001$ vs. control under HBO; ${ }^{\dagger} \mathrm{P}<0.05$ and ${ }^{\dagger \dagger} \mathrm{P}<0.001$ as indicated. HBO, hyperbaric oxygen; ZKK-3, N,N'-dimethyl-S-(2,3,4,5,6-pentabromobenzyl)-isothiouronium bromide.
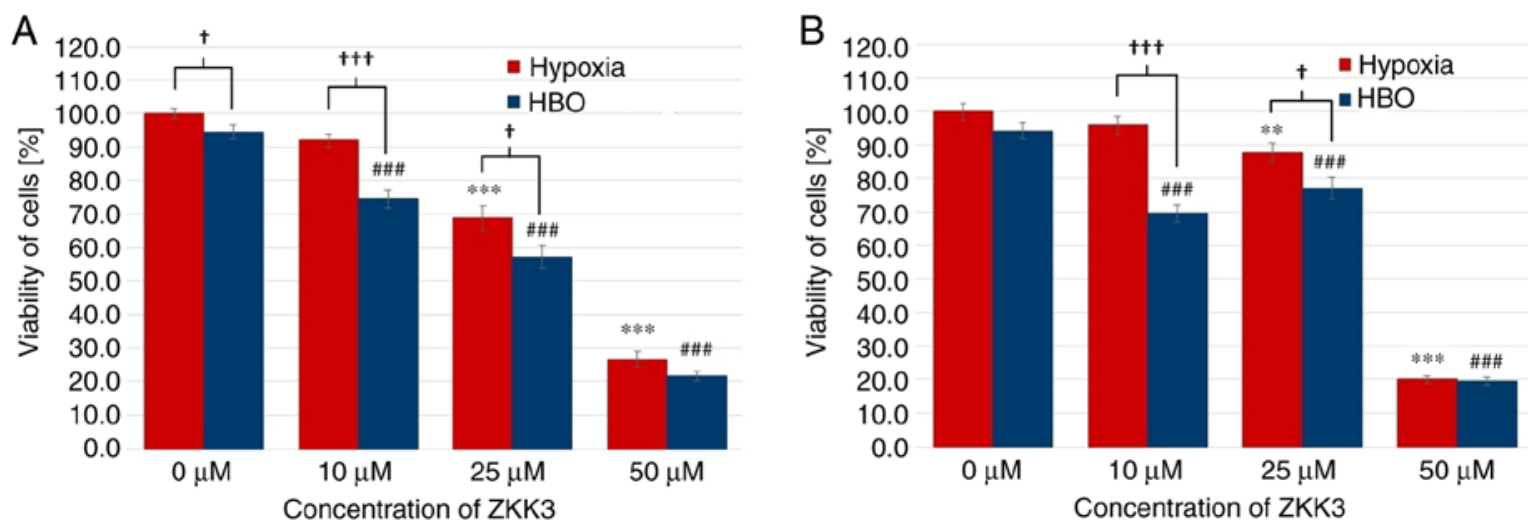

Figure 9. Viability of T98G cells treated with ZKK-3 under hypoxia and HBO. Influence of hypoxia and HBO on the viability of T98G cells following (A) $24 \mathrm{~h}$ and (B) $48 \mathrm{~h}$ of incubation with ZKK-3. ${ }^{* *} \mathrm{P}<0.01$ and ${ }^{* * *} \mathrm{P}<0.001$ vs. control under in hypoxia; ${ }^{\# \# \#} \mathrm{P}<0.001$ vs. control under HBO; ${ }^{\dagger} \mathrm{P}<0.05$ and ${ }^{\dagger \dagger} \mathrm{P}<0.001$ as indicated. HBO, hyperbaric oxygen; ZKK-3, N,N'-dimethyl-S-(2,3,4,5,6-pentabromobenzyl)-isothiouronium bromide.

Expression levels of HIF-1 $\alpha$. HIF-1 $\alpha$ expression levels in lysates of cells cultured without ZKK-3 were analyzed. It was identified that the HIF protein expression levels were significantly increased under hypoxia (287\%), HBO (56\%), and hypoxia/hypoxia (346\%) compared with cells under normoxia (Fig. 10). Under hypoxia/hypoxia, protein expression was also increased with the addition of 10 and $50 \mu \mathrm{M}$ ZKK-3 (by 78 and 194\%, respectively) compared with the respective normoxia groups. Furthermore, significantly decreased HIF-1 $\alpha$ expression was observed in cells exposed to hypoxia/HBO with 25 and $50 \mu \mathrm{M} \mathrm{ZKK-3} \mathrm{(by} 33$ and $68 \%$, respectively) when compared with the respective normoxia groups. Significantly decreased levels of HIF- $1 \alpha$ were also indicated for cells under hypoxia/hypoxia at $25 \mu \mathrm{M}$ ZKK-3 when compared with normoxia. HBO alone caused the protein expression level to significantly decrease by $60 \%$ relative to hypoxia without ZKK-3 treatment; however, decreases observed with ZKK-3 treatment were not statistically significant. Notably, HIF-1 $\alpha$ expression was significantly reduced under hypoxia/HBO compared with hypoxia/hypoxia in control groups (64\%) and cells treated with 10 and $50 \mu \mathrm{M}$ ZKK-3 (45 and 89\%, respectively).

Expression levels of PKD1 and its phosphorylated forms. In GBM cells under short-term and long-term hypoxia, PKD1 expression levels were similar or marginally reduced compared with cells under normoxia in control and ZKK-3-treated groups (Fig. 11A). However, PKD1 expression levels were increased in cells under HBO and hypoxia/HBO conditions compared with normoxia when 0 and $50 \mu \mathrm{M}$ ZKK-3 was applied. ZKK-3 at 25 and $50 \mu \mathrm{M}$ seemed to decrease PKD1 levels under all examined oxygen conditions, compared with the controls. However, differences in total PKD1 expression levels in T98G cells under different oxygen conditions and ZKK-3 treatments were not statistically significant (Fig. 11B).

Increasing ZKK-3 concentrations were associated with decreasing pPKD1 (Ser 916) expression levels, regardless of the oxygen conditions (Fig. 12A). In control groups ( $0 \mu \mathrm{M}$ ZKK-3), compared with the normoxia group, there were significant reductions of pPKD1 (Ser 916) expression levels in cells under hypoxia, HBO and hypoxia/hypoxia (Fig. 12B). Following the addition of $50 \mu \mathrm{M}$ ZKK-3, pPKD1 (Ser 916) expression levels were reduced under hypoxia-hypoxia and elevated under hypoxia/HBO when compared with normoxia. Notably, there were no significant differences between cells cultured under hypoxia and HBO conditions. However, treatment with $50 \mu \mathrm{M}$ ZKK-3 yielded a statistically significant decrease in pPKD1 (Ser 916) expression under all examined oxygen conditions compared with the respective controls: 59\% for normoxia, $44 \%$ for hypoxia, $45 \%$ for $\mathrm{HBO}, 68 \%$ for hypoxia/hypoxia and 


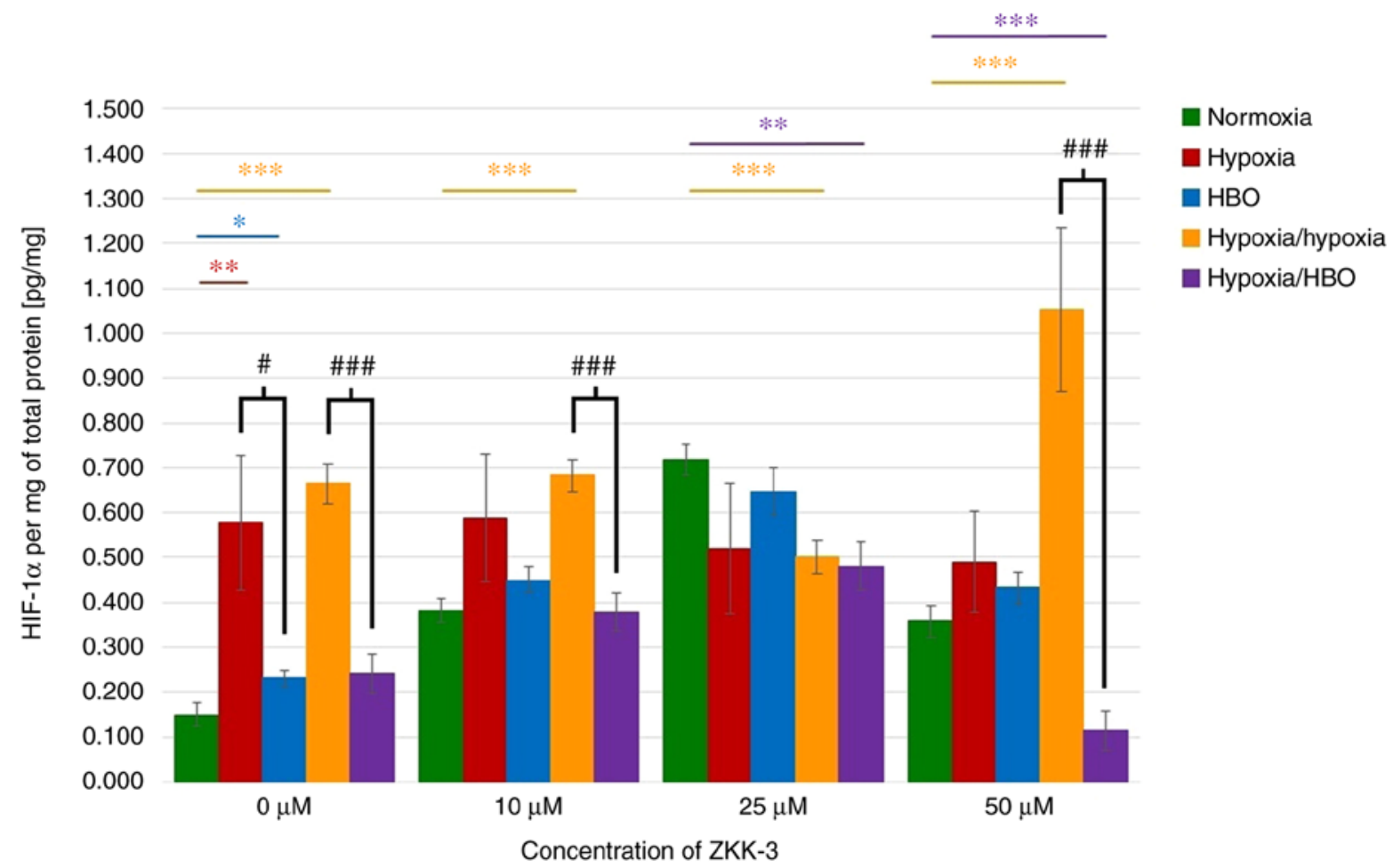

Figure 10. Expression of HIF-1 $\alpha$ in T98G cells treated with ZKK-3. Impact of different oxygen conditions on the expression of HIF-1 $\alpha$ protein in T98G cells following $24 \mathrm{~h}$ of incubation with ZKK-3 was determined using an ELISA assay. ${ }^{*} \mathrm{P}<0.05,{ }^{* *} \mathrm{P}<0.01$ and ${ }^{* * *} \mathrm{P}<0.001$ as indicated; ${ }^{\#} \mathrm{P}<0.05$ and ${ }^{\# \# \#} \mathrm{P}<0.001$ as indicated. HBO, hyperbaric oxygen; ZKK-3, N,N'-dimethyl-S-(2,3,4,5,6-pentabromobenzyl)-isothiouronium bromide; HIF-1 $\alpha$, hypoxia-inducible factor-1 $\alpha$.
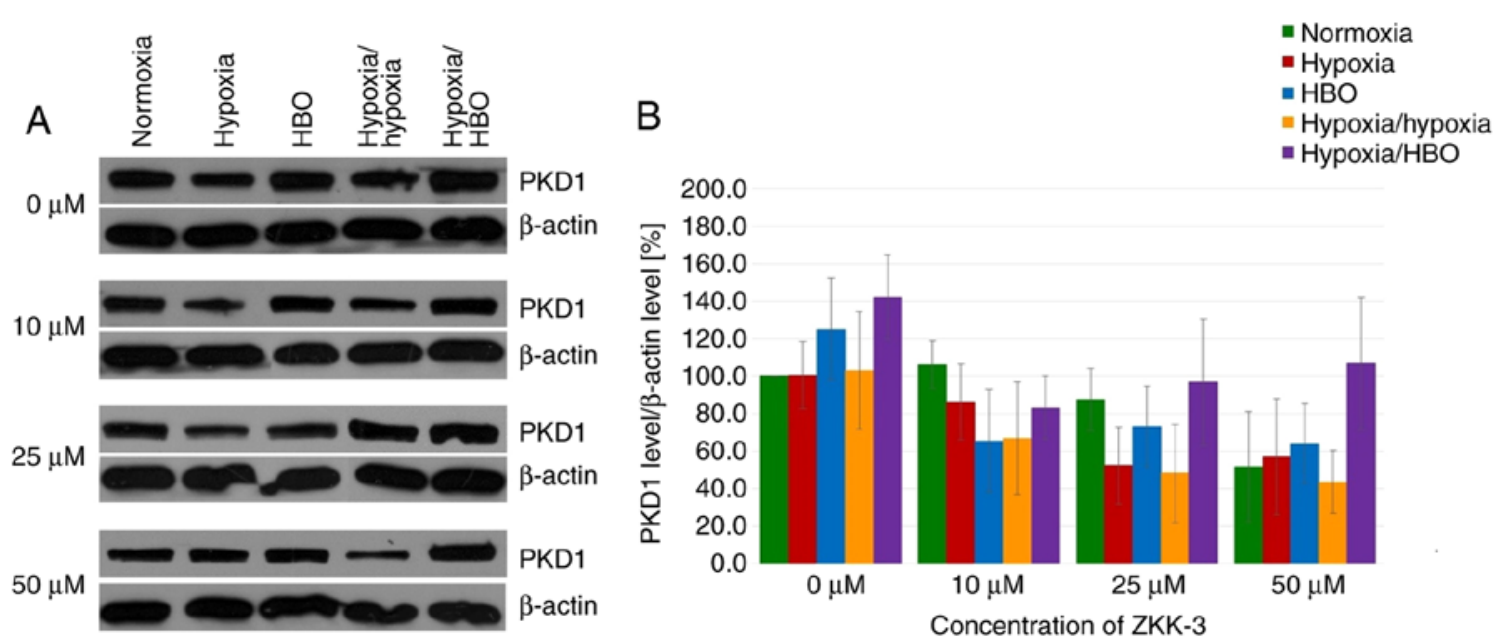

Figure 11. Expression of PKD1 in T98G cells treated with ZKK-3. (A) Expression of PKD1 kinase in T98G cells treated with ZKK-3 and different oxygen conditions was determined using western blot analysis. (B) Impact of ZKK-3 and different oxygen conditions on the expression of PKD1 kinase in T98G cells following $24 \mathrm{~h}$ of incubation. Normoxia at $0 \mu \mathrm{M}$ ZKK-3 represents a reference level of PKD1 expression. PKD1, protein kinase D1; HBO, hyperbaric oxygen; ZKK-3, N,N'-dimethyl-S-(2,3,4,5,6-pentabromobenzyl)-isothiouronium bromide.

$50 \%$ for hypoxia/HBO. However, the phospho/total ratio of pPKD1 demonstrated a significant reduction of expression in the control groups ( $0 \mu \mathrm{M}$ ZKK-3). In addition, pPKD1 expression was decreased under hypoxia/hypoxia and hypoxia/HBO at $50 \mu \mathrm{M}$ ZKK-3 (Fig. 12C).

Western blot analysis revealed that hypoxia and $\mathrm{HBO}$ conditions resulted in significantly increased pPKD1 (Ser 744/748) expression levels compared with normoxia, in both control and ZKK-3-treated T98G cells (Fig. 13A). pPKD1 (Ser 744/748) expression level seemed similar compared with controls $(0 \mu \mathrm{M}$
ZKK-3) following treatment with lower ZKK-3 concentrations under all oxygen conditions; however, $50 \mu \mathrm{M}$ ZKK-3 led to marked elevation irrespective of oxygen conditions. Statistical analysis revealed that the pPKD1 (Ser 744/748) expression level increased under the influence of oxygen pressure changes compared with normoxia; however, the change was only significant under hypoxia/HBO in control groups, which indicated a nearly 2.5 -fold rise (Fig. 13B). No significant differences were observed between cells precultured under the same oxygen conditions with different ZKK-3 treatment, with the 

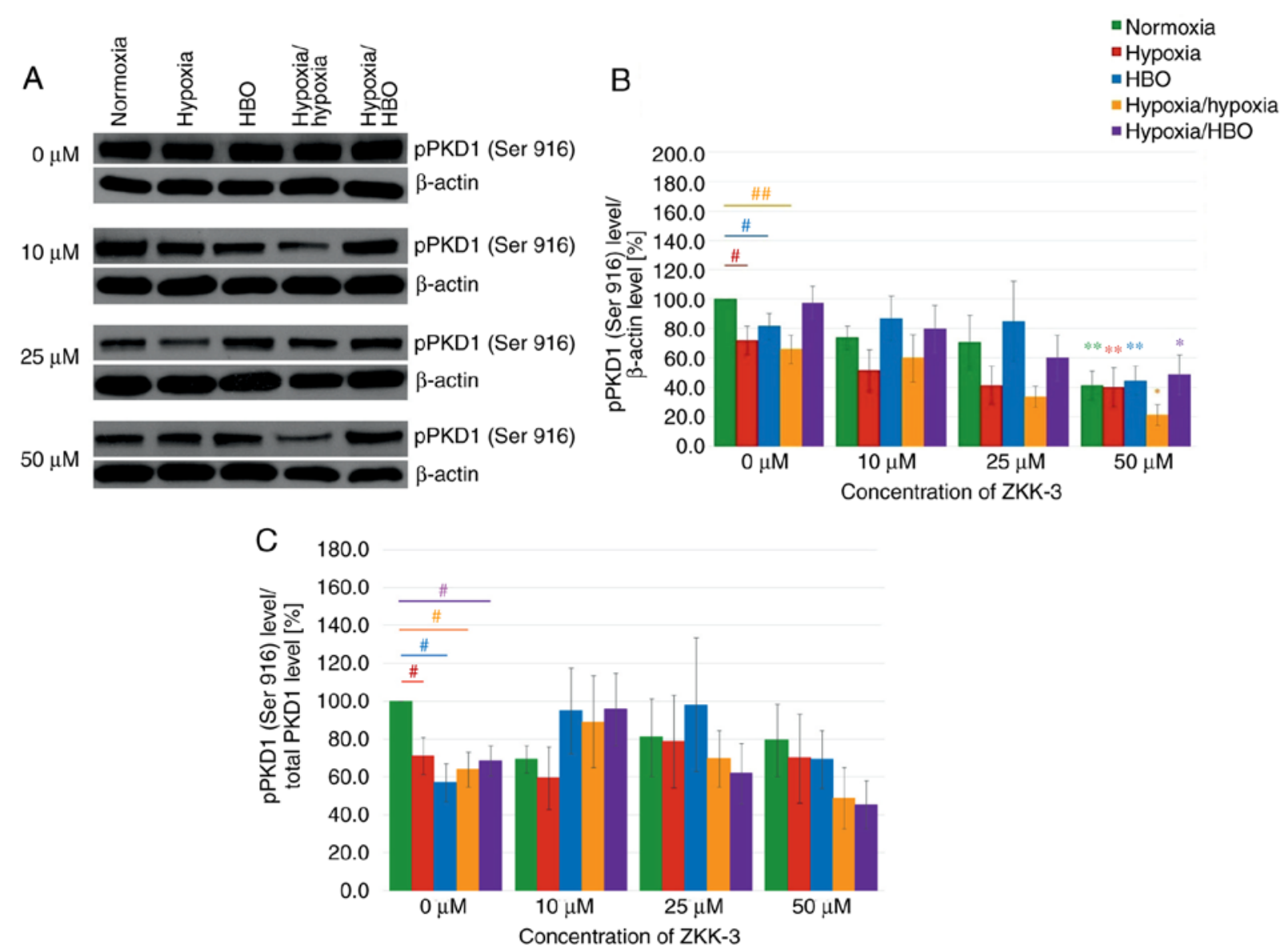

Figure 12. Expression of pPKD1 (Ser 916) in T98G cells treated with ZKK-3 following 24 h of incubation. (A) Expression of pPKD1 (Ser 916) kinase in T98G cells treated with ZKK-3 and different oxygen conditions was determined using western blot analysis. (B) Impact of ZKK-3 and different oxygen conditions on the expression of pPKD1 (Ser 916) kinase. (C) Impact of ZKK-3 and different oxygen conditions on the expression of pPKD1 (Ser 916) kinase calculated as pPKD1(Ser 916)/total PKD1 ratio. Normoxia at $0 \mu \mathrm{M}$ ZKK-3 represents a reference level of pPKD1 (Ser 916) expression. "P<0.05 and ${ }^{* *} \mathrm{P}<0.01 \mathrm{vs.}$ control under corresponding oxygen conditions; ${ }^{\#} \mathrm{P}<0.05$ and ${ }^{\# \#} \mathrm{P}<0.01$ as indicated. pPKD1, phosphorylated protein kinase D1; HBO, hyperbaric oxygen; ZKK-3, N,N'-dimethyl-S-(2,3,4,5,6-pentabromobenzyl)-isothiouronium bromide.

exception of cells treated with $50 \mu \mathrm{M} \mathrm{ZKK-3,} \mathrm{which} \mathrm{resulted}$ in statistically significant increase of pPKD1 (Ser 744/748) expression level under normoxia (158\%) and hypoxia (133\%) compared with the respective controls. This was confirmed when analyzing the phospho/total ratio of pPKD1. The treatment of $50 \mu \mathrm{M}$ ZKK-3 was associated with significant increase of pPKD1 (Ser 744/748) expression in all oxygen conditions except hypoxia/HBO compared with the controls (Fig. 13C).

\section{Discussion}

The medical treatment of patients with GBM remains challenging as multiple treatment approaches do not provide satisfactory therapeutic effects $(2,5,6)$. Therefore, intensive research is focused on developing novel treatment strategies. S-benzylisothiourea derivatives have been investigated, with in vitro results validating their proapoptotic and cytotoxic properties against various neoplastic cells, including several types of leukemia $(20,21)$, prostate adenocarcinoma (22) and glioma $(19,26)$. Furthermore, compounds from this group have demonstrated greater cytotoxicity against human glioblastoma cells in vitro compared with the clinically used compound temozolomide (26). However, ZKKs (including ZKK-3) also demonstrated cytotoxic activity against normal human astrocytes in vitro (26), and this effect should therefore be taken into account when considering anticancer therapy. The cytotoxic effect of ZKKs towards normal glial elements of brain tissue could be eliminated by modern methods of precise and direct delivery of compounds to the tumor tissue. Notably, the present results demonstrated that treatment with ZKK-3 dose dependently resulted in the reduction of T98G proliferation and viability.

Numerous studies have revealed that poor tumor tissue oxygenation is a pivotal factor in the development of malignancies, including gliomas, and can foster radiotherapy and chemotherapy resistance $(7,8,27)$. The present results demonstrated that anoxia resulted in significantly reduced cell growth compared with normoxia. Under anaerobic conditions, GBM cell proliferation declined following ZKK-3 administration; however, this decrease was not as severe when compared with standard conditions. Notably, cell viability was significantly increased in control and experimental groups under anoxia compared with normoxia. Under anoxic conditions, significant cytotoxic effects were only observed with higher ZKK-3 doses or prolonged exposure. These findings may indicate that, despite the impact of anoxia on cell proliferation, the cell viability can be ameliorated by low oxygen conditions, possibly due to activation of HIF-1 $\alpha$ adaptive responses. Independent 

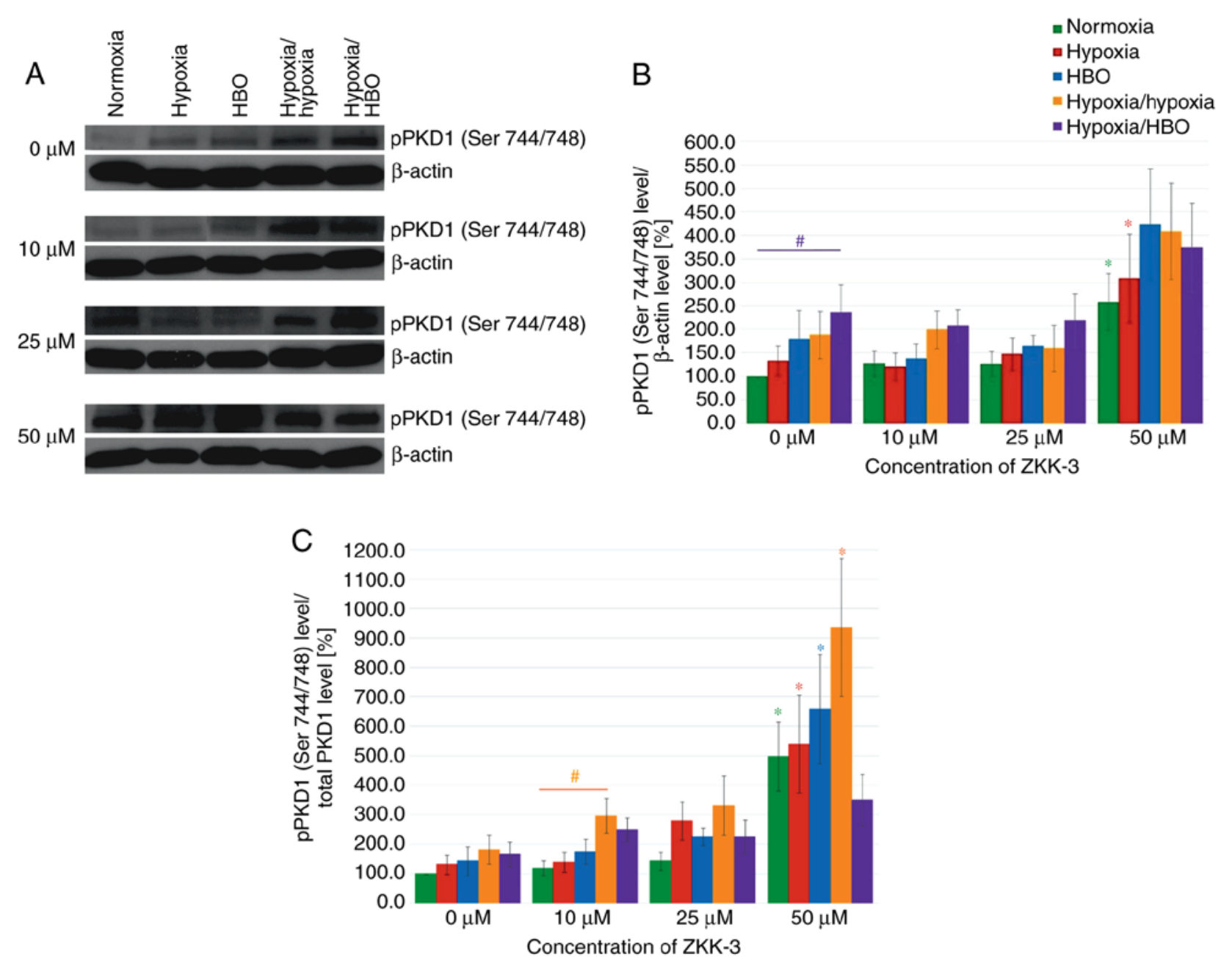

Figure 13. Expression of pPKD1 (Ser 744/748) in T98G cells treated with ZKK-3 in T98G cells following 24 h of incubation. (A) Expression of pPKD1 (Ser 744/748) kinase in T98G cells treated with ZKK-3 and different oxygen conditions was determined using western blot analysis. (B) Impact of ZKK-3 and different oxygen conditions on the expression of pPKD1 (Ser 744/748) kinase. (C) Impact of ZKK-3 and different oxygen conditions on the expression of pPKD1 (Ser 744/748) kinase calculated as pPKD1(Ser 744/748)/total PKD1 ratio. Normoxia at $0 \mu \mathrm{M} Z$ ZKK-3 represents a reference level of pPKD1 (Ser 744/748) expression. ${ }^{*} \mathrm{P}<0.05$ vs. control under corresponding oxygen conditions; ${ }^{*} \mathrm{P}<0.05$ as indicated. pPKD1, phosphorylated protein kinase D1; HBO, hyperbaric oxygen; ZKK-3, N,N'-dimethyl-S-(2,3,4,5,6-pentabromobenzyl)-isothiouronium bromide.

of these discrepancies, the present results suggest that oxygen deprivation impaired the antitumor properties of ZKK-3. However, relevant data from the literature are somewhat contradictory. Liang (28) also reported that GBM cells are less sensitive to several chemotherapeutics under anaerobic conditions. By contrast, Papandreou et al (29) revealed decreased viability and higher apoptotic potential of various tumor cell lines under anoxia.

In the present study, hypoxia alone caused a slight reduction of T98G cell line viability, but did not change GBM cell proliferation relative to normoxia. A statistically significant reduction of the number of GBM cells was observed following treatment with 25 and $50 \mu \mathrm{M}$ ZKK-3, regardless of the oxygen conditions. However, following incubation with $50 \mu \mathrm{M}$ ZKK-3, cell proliferation was significantly higher under low oxygen concentration compared with standard conditions. Furthermore, under hypoxia, only high-dose ZKK-3 (50 $\mu \mathrm{M})$ significantly reduced $\mathrm{T} 98 \mathrm{G}$ cell viability compared with normoxia after 2 days of exposure. After $48 \mathrm{~h}$ of incubation with 10 and $25 \mu \mathrm{M}$ ZKK-3, cell viability was higher under low-oxygen conditions compared with that under normoxia.
The present results support the conclusion that prolonged exposure to hypoxia significantly reduced the sensitivity of neoplastic cells to ZKK-3 within a certain concentration range. Following long-term incubation with $50 \mu \mathrm{M}$ ZKK-3, inhibition of its cytotoxic effects under hypoxia was no longer indicated.

Notably, Osawa et al (30) did not identify altered T98G GBM cell growth following exposure to hypoxia conditions. Furthermore, proliferation of spheroid-building cells is reportedly similar between low-oxygen environments and normoxia (31). Studies conducted using a human prostate cancer cell line suggest that hypoxia significantly reduces cell viability and migration (32). However, the authors observed that oxygen deficiency also promoted the chemotherapy resistance of tumor cells. This association between the hypoxic tumor environment and drug resistance has also been documented in other malignancies in vitro $(33,34)$. Overall, these studies suggest that hypoxia can either impair or promote the antitumor properties of chemotherapeutics, depending on the type of cytotoxic compound and the tumor cell line $(33,35)$. Previous results have also demonstrated the reduction of 
GBM cell sensitivity to radiotherapy in a low-oxygen environment (36).

It has been postulated that $\mathrm{HBO}$ may be a promising method of improving tissue oxygenation (14-16); however, some reports suggest that aggressive HBO treatment, different from our protocol, may promote tumor progression $(37,38)$. The present results suggested that HBO applied alone did not significantly alter the number and viability of the GBM cell line relative to standard or oxygen-deficiency conditions. However, combined application of ZKK-3 and HBO resulted in significantly reduced proliferation and viability of $\mathrm{T} 98 \mathrm{G}$ cells compared with cells under normoxia and hypoxia. It is noteworthy that hypoxia corresponds to the physiological conditions of tumor tissue in vivo. Notably, cells demonstrated higher sensitivity to ZKK-3 under HBO compared with hypoxia, irrespective of the duration of exposure. Under the influence of $\mathrm{HBO}$, a significantly decreased number of living GBM cells was observed, even at lower ZKK-3 concentrations and after reduced exposure time to $\mathrm{ZKK}-3 / \mathrm{HBO}$.

Data from the literature suggest that HBO administration can significantly improve the effectiveness of standard antitumor procedures, including chemotherapy and radiotherapy (16,39-41). Results indicate that HBO can enhance the cytotoxic effect of various chemotherapeutic agents towards various types of tumors in vivo and in vitro (42-45). Such combined therapy seems to be particularly promising in gliomas. Sun et al (46) demonstrated that maintaining a GBM cell line under hyperoxic conditions, even under normobaric pressure, increases its sensitivity to the commonly used compound temozolomide. HBO used as an adjuvant to temozolomide significantly inhibits GBM cell growth in vitro and increases apoptosis (47). HBO-induced improvement of the antiproliferative properties of temozolomide has also been observed in GBM in vivo (48). Similar results are reported following treatment with combined $\mathrm{HBO}$ and nimustine in a mouse model of glioma (49). Clinical trials of glioma treatment using HBO combined with radiotherapy and chemotherapy have also produced encouraging results, including regression of tumor growth and prolonged patient survival (50-54).

HIF-1 is crucial in regulating tumor cell adaptations to hypoxic conditions, which further contributes to their treatment resistance $(8,11,12)$. Zhou et al $(55)$ examined HIF expression in tumor cells of various origins in vitro under different oxygen conditions. The study concluded that reduced oxygen partial pressure led to increased HIF levels in all examined cell lines. Other investigators have also reported enhanced expression levels of HIF-1 $\alpha$ and its downstream genes (vascular endothelial growth factor, glucose transporter 1, glucose transporter 3 and pyruvate dehydrogenase kinase 1) under hypoxia compared with standard conditions $(33,56)$. Furthermore, Liu et al (57) identified that higher HIF-1 $\alpha$ levels promoted the development of drug resistance and survival in cancer cell lines. Additionally, HIF-1 $\alpha$ reportedly leads to increased levels of multidrug resistance protein 1 and antiapoptotic genes (B-cell lymphoma-2), along with decreased expression of the proapoptotic B-cell lymphoma-2 associated $\mathrm{X}$ protein. Furthermore, survivin, an inhibitor of apoptosis, is expressed in the majority of cancer cells and may contribute to the anticancer therapy resistance $(58,59)$. The role of survivin in glioma progression was evaluated and its association with poorer prognosis was suggested (60). As inhibition of ionizing radiation resistance of human T98 GBM cells after survivin gene silencing has been documented (61), the involvement of survivin on the effect of ZKKs or ZKK-3 should be clarified in the future. Notably, hypoxic conditions promote greater HIF-1 $\alpha$ expression in GBM $(36,62)$. Furthermore, numerous studies suggest elevated HIF activity in GBM under normoxic conditions, which is further enhanced under hypoxia $(8,55,63)$.

Efforts have been made to reduce HIF-1 $\alpha$ expression using specific inhibitors or small interfering RNA silencing $(64,65)$. Unfortunately, few studies have examined the influence of $\mathrm{HBO}$ on these protein expression levels in tumor cells. Notably, some data indicate that oxygenation may help decrease HIF levels $(49,66)$. However, other reports have demonstrated that HBO exerts no effect or even promotes HIF-1 $\alpha$ expression $(37,67,68)$. Thus, the issue remains controversial. The present results indicated that the HIF-1 $\alpha$ protein expression level in T98G cells was dependent on the oxygen conditions. Under hypoxia and no ZKK-3 treatment, HIF-1 $\alpha$ expression was significantly elevated compared with normoxia. A prolonged duration of oxygen deficiency (preincubation under hypoxia prior to ZKK-3 administration, i.e., hypoxia/hypoxia) resulted in an even greater increase of HIF-1 $\alpha$ expression. Notably, HIF-1 $\alpha$ expression under hypoxia/HBO was significantly suppressed relative to hypoxia/hypoxia without ZKK-3 and with 10 and $50 \mu \mathrm{M}$ ZKK-3 treatment. The elevated HIF-1 $\alpha$ protein level under hypoxia and its reduction under $\mathrm{HBO}$ suggest that $\mathrm{HBO}$ may reduce treatment resistance of neoplastic cells.

Abnormal PKD1 activity serves important roles in various malignancies (69). Therefore, numerous studies have been undertaken to develop effective suppressors of this kinase in various tumor cells (70-72). Unfortunately, the developed PKD1 inhibitors exhibit poor selectivity. Koronkiewicz et al $(21,22)$ reported that $10 \mu \mathrm{M}$ ZKK-3 may inhibit PKD1 expression by $\sim 70 \%$ in human cell lines of prostate adenocarcinoma and acute myelogenous leukemia. However, their reports do not provide detailed information regarding the duration of incubation with ZKK-3, or whether the results are associated with the total kinase level or only to the level of its non-phosphorylated form. Other research performed in the T98G cell line indicates that a 48-h incubation with $10 \mu \mathrm{M}$ ZKK-3 does not alter PKD1 expression, but significantly decreases the expression level of pPKD1 (Ser 916) (26). The present results indicated that ZKK-3 did not significantly change the expression of total PKD1 in GBM cells in vitro. However, $24 \mathrm{~h}$ incubation with $50 \mu \mathrm{M}$ ZKK-3 resulted in a statistically significant decrease of the phosphorylated form of pPKD1 (Ser 916) and increased the level of pPKD1 (Ser 744/748) compared with the respective controls. Therefore, it seems possible that ZKK-3 prevented PKD1 phosphorylation at Ser 916, resulting in a reduction of pPKD1 (Ser 916) and accumulation of pPKD1 (Ser 744/748).

Generally, the expression levels of PKD1 and its phosphorylated forms were not significantly different in T98G cells under different oxygen conditions, including those under $\mathrm{HBO}$, in the control and in ZKK-3-treated groups. This suggests that modulation of PKD1 activity may not be a leading mechanism underlying the cytotoxic activity of ZKK-3 combined with HBO. However, it is noteworthy that hypoxia/HBO tended to reduce the increase of the level of pPKD1 (Ser 744/748) 
normalized to total PKD1 (pPKD1/total PKD1 ratio) at $50 \mu \mathrm{M}$ ZKK-3. Previous studies investigating the influence of the oxygenation state of cells on PKD1 expression have produced ambiguous results. Some indicate that hypoxia conditions result in PKD1 phosphorylation and activation (73-75), while others report no significant changes in the expression of this kinase $(73,76)$.

In conclusion, application of $\mathrm{HBO}$ significantly reduced the proliferation of malignant GBM cells in vitro, and increased their sensitivity to the isothiourea derivative ZKK-3. The beneficial cytotoxic effects of ZKK-3/HBO could be achieved using lower concentrations of ZKK-3 and reduced exposure time. The decreased level of HIF-1 $\alpha$ protein expression under HBO suggests that HBO improved cell oxygenation, and thus may help reduce tumor cell resistance to cytostatic compounds. Although ZKK-3 exhibited inhibitory properties against pPKD1 (Ser 916) kinase, various oxygen conditions, including hyperbaric oxygenation, did not influence the expression of PKD1 or its phosphorylated forms. Overall, the present findings suggest that the combination of ZKK-3 and HBO may be a promising therapeutic approach for the treatment of brain tumors with the highest grade of histological malignancy. Further studies are required to investigate this possibility.

\section{Acknowledgements}

Not applicable.

\section{Funding}

The research was supported by the Leading National Research Centre-Mossakowski Medical Research Centre (KNOW-MMRC) project and partially by Foundation for the Development of Diagnostic and Therapy.

\section{Availability of data and materials}

All data generated or analyzed during this study are included in this published article.

\section{Authors' contributions}

$\mathrm{KZ}$ performed the experiments, analyzed the experiment data and wrote the manuscript. RPO made contribution to conception of the study and assisted in the western blot analysis. EM made contributions to the conception and design of the study and interpreted the data. RPO and EM revised the manuscript. All authors read and approved the final submission.

\section{Ethics approval and consent to participate}

Not applicable.

\section{Patient consent for publication}

Not applicable.

\section{Competing interests}

The authors declare that they have no competing interests.

\section{References}

1. Batash R, Asna N, Schaffer P, Francis N and Schaffer M: Glioblastoma multiforme, diagnosis and treatment; recent literature review. Curr Med Chem 24: 3002-3009, 2017.

2. Davis ME: Glioblastoma: Overview of disease and treatment. Clin J Oncol Nurs 20 (Suppl 5): S2-S8, 2016.

3. Hanif F, Muzaffar K, Perveen K, Malhi SM and Simjee ShU: Glioblastoma multiforme: A review of its epidemiology and pathogenesis through clinical presentation and treatment. Asian Pac J Cancer Prev 18: 3-9, 2017.

4. Liao W, Fan S, Zheng Y, Liao S, Xiong Y, Li Y and Liu J: Recent advances on glioblastoma multiforme and nano-drug carriers: A review. Curr Med Chem, 2018.

5. Hegi ME, Diserens AC, Gorlia T, Hamou MF, de Tribolet N, Weller M, Kros JM, Hainfellner JA, Mason W, Mariani L, et al: MGMT gene silencing and benefit from temozolomide in glioblastoma. N Engl J Med 352: 997-1003, 2005.

6. Lee SY: Temozolomide resistance in glioblastoma multiforme. Genes Dis 3: 198-210, 2016.

7. Höckel M and Vaupel P: Tumor hypoxia: Definitions and current clinical, biologic, and molecular aspects. J Natl Cancer Inst 93: 266-276, 2001.

8. Jensen RL: Brain tumor hypoxia: Tumorigenesis, angiogenesis, imaging, pseudoprogression, and as a therapeutic target. J Neurooncol 92: 317-335, 2009.

9. Rockwell S, Dobrucki IT, Kim EY, Marrison ST and Vu VT: Hypoxia and radiation therapy: Past history, ongoing research, and future promise. Curr Mol Med 9: 442-458, 2009.

10. Daruwalla J and Christophi C: Hyperbaric oxygen therapy for malignancy: A review. World J Surg 30: 2112-2131, 2006.

11. Vaupel P: The role of hypoxia-induced factors in tumor progression. Oncologist 9 (Suppl 5): S10-S17, 2004.

12. Yang L, Lin C, Wang L, Guo H and Wang X: Hypoxia and hypoxia-inducible factors in glioblastoma multiforme progression and therapeutic implications. Exp Cell Res 318: 2417-2426, 2012.

13. Ostrowski RP and Zhang JH: The insights into molecular pathways of hypoxia-inducible factor in the brain. J Neurosci Res, 2018.

14. Al-Waili NS, Butler GJ, Beale J, Hamilton RW, Lee BY and Lucas P: Hyperbaric oxygen and malignancies: A potential role in radiotherapy, chemotherapy, tumor surgery and phototherapy. Med Sci Monit 11: RA279-289, 2005.

15. Moen I and Stuhr LE: Hyperbaric oxygen therapy and cancer-a review. Target Oncol 7: 233-242, 2012.

16. Stepien K, Ostrowski RP and Matyja E: Hyperbaric oxygen as an adjunctive therapy in treatment of malignancies, including brain tumours. Med Oncol 33: 101, 2016.

17. Gill AL and Bell CN: Hyperbaric oxygen: Its uses, mechanisms of action and outcomes. QJM 97: 385-395, 2004.

18. Mayer R, Hamilton-Farrell MR, van der Kleij AJ, Schmutz J, Granström G, Sicko Z, Melamed Y, Carl UM, Hartmann KA, Jansen EC, et al: Hyperbaric oxygen and radiotherapy. Strahlenther Onkol 181: 113-123, 2005.

19. Kaminska B, Ellert-Miklaszewska A, Oberbek A, Wisniewski P, Kaza B, Makowska M, Bretner M and Kazimierczuk Z: Efficacy and mechanism of antitumor action of new potential CK2 inhibitors toward glioblastoma cells. Int J Oncol 35: 1091-1100, 2009.

20. Koronkiewicz M, Chilmonczyk Z and Kazimierczuk Z: Proapoptotic effects of novel pentabromobenzylisothioureas in human leukemia cell lines. Med Chem Res 21: 3111-3118, 2012.

21. Koronkiewicz M, Chilmonczyk Z and Kazimierczuk Z: Synergistic anti-leukemic effects of CK2 inhibitors and pentabromobenzylisothioureas in vitro. Anticancer Res 33: 4891-4899, 2013.

22. Koronkiewicz M, Kazimierczuk Z, Szarpak K and Chilmonczyk Z: Proapoptotic effects of new pentabromobenzylisothiouronium salts in a human prostate adenocarcinoma cell line. Acta Pol Pharm 69: 1325-1333, 2012.

23. Sundram V, Chauhan SC and Jaggi M: Emerging roles of protein kinase D1 in cancer. Mol Cancer Res 9: 985-996, 2011.

24. Eiseler T, Doppler H, Yan IK, Goodison S and Storz P: Protein kinase D1 regulates matrix metalloproteinase expression and inhibits breast cancer cell invasion. Breast Cancer Res 11: R13, 2009.

25. Wille C, Seufferlein T and Eiseler T: Protein Kinase D family kinases: Roads start to segregate. Bioarchitecture 4: 111-115, 2014.

26. Pucko E, Matyja E, Koronkiewicz M, Ostrowski RP and Kazimierczuk Z: Potent antitumour effects of novel pentabromobenzylisothioureas studied on human glial-derived tumour cell lines. Anticancer Res 38: 2691-2705, 2018. 
27. Muz B, de la Puente P, Azab F and Azab AK: The role of hypoxia in cancer progression, angiogenesis, metastasis, and resistance to therapy. Hypoxia (Auckl) 3: 83-92, 2015.

28. Liang BC: Effects of hypoxia on drug resistance phenotype and genotype in human glioma cell lines. J Neurooncol 29: 149-155, 1996.

29. Papandreou I, Krishna C, Kaper F, Cai D, Giaccia AJ and Denko NC: Anoxia is necessary for tumor cell toxicity caused by a low-oxygen environment. Cancer Res 65: 3171-3178, 2005.

30. Osawa T, Tsuchida R, Muramatsu M, Yuasa Y and Shibuya M: Human glioblastoma cells exposed to long-term hypoxia and nutrient starvation stimulated induction of secondary T-cell leukemia in mice. Blood Cancer J 1: e6, 2011.

31. Riffle S, Pandey RN, Albert M and Hegde RS: Linking hypoxia, DNA damage and proliferation in multicellular tumor spheroids. BMC Cancer 17: 338, 2017.

32. Mamede AC, Abrantes AM, Pedrosa L, Casalta-Lopes JE, Pires AS, Teixo RJ, Gonçalves AC, Sarmento-Ribeiro AB, Maia CJ and Botelho MF: Beyond the limits of oxygen: Effects of hypoxia in a hormone-independent prostate cancer cell line. ISRN Oncol 2013: 918207, 2013.

33. Yao K, Gietema JA, Shida S, Selvakumaran M, Fonrose X, Haas NB, Testa J and O'Dwyer PJ: In vitro hypoxia-conditioned colon cancer cell lines derived from HCT116 and HT29 exhibit altered apoptosis susceptibility and a more angiogenic profile in vivo. Br J Cancer 93: 1356-1363, 2005.

34. Qian J, Shen S, Chen W and Chen N: Propofol reversed Hypoxia-induced docetaxel resistance in prostate cancer cells by preventing epithelial-mesenchymal transition by inhibiting Hypoxia-lnducible factor l $\alpha$. Biomed Res Int 2018: 4174232, 2018.

35. Strese S, Fryknäs M, Larsson R and Gullbo J: Effects of hypoxia on human cancer cell line chemosensitivity. BMC Cancer 13 : 331,2013

36. Hsieh $\mathrm{CH}$, Lee $\mathrm{CH}$, Liang JA, Yu CY and Shyu WC: Cycling hypoxia increases U87 glioma cell radioresistance via ROS induced higher and long-term HIF-1 signal transduction activity. Oncol Rep 24: 1629-1636, 2010.

37. Ding JB, Chen JR, Xu HZ and Qin ZY: Effect of hyperbaric oxygen on the growth of intracranial glioma in rats. Chin Med J (Engl) 128: 3197-3203, 2015.

38. Wang YG, Zhan YP, Pan SY, Wang HD, Zhang DX, Gao K, Qi XL and Yu CJ: Hyperbaric oxygen promotes malignant glioma cell growth and inhibits cell apoptosis. Oncol Lett 10: $189-195,2015$.

39. Kohshi K, Kinoshita Y, Terashima H, Konda N, Yokota A and Soejima T: Radiotherapy after hyperbaric oxygenation for malignant gliomas: A pilot study. J Cancer Res Clin Oncol 122: 676-678, 1996.

40. Kohshi K, Kinoshita Y, Imada H, Kunugita N, Abe H, Terashima $\mathrm{H}$, Tokui $\mathrm{N}$ and Uemura $\mathrm{S}$ : Effects of radiotherapy after hyperbaric oxygenation on malignant gliomas. $\mathrm{Br}$ J Cancer 80: 236-241, 1999.

41. Kohshi K, Beppu T, Tanaka K, Ogawa K, Inoue O, Kukita I and Clarke RE: Potential roles of hyperbaric oxygenation in the treatments of brain tumors. Undersea Hyperb Med 40: 351-362, 2013

42. Stuhr LE, Iversen VV, Straume O, Maehle BO and Reed RK: Hyperbaric oxygen alone or combined with 5-FU attenuates growth of DMBA-induced rat mammary tumors. Cancer Lett 210: 35-40, 2004

43. Granowitz EV, Tonomura N, Benson RM, Katz DM, Band V, Makari-Judson GP and Osborne BA: Hyperbaric oxygen inhibits benign and malignant human mammary epithelial cell proliferation. Anticancer Res 25: 3833-3842, 2005.

44. Kawasoe Y, Yokouchi M, Ueno Y, Iwaya H, Yoshida H and Komiya S: Hyperbaric oxygen as a chemotherapy adjuvant in the treatment of osteosarcoma. Oncol Rep 22: 1045-1050, 2009.

45. Ohgami Y, Elstad CA, Chung E, Shirachi DY, Quock RM and Lai HC: Effect of hyperbaric oxygen on the anticancer effect of artemisinin on molt-4 human leukemia cells. Anticancer Res 30: 4467-4470, 2010.

46. Sun S, Lee D, Lee NP, Pu JK, Wong ST, Lui WM, Fung CF and Leung GK: Hyperoxia resensitizes chemoresistant human glioblastoma cells to temozolomide. J Neurooncol 109: 467-475, 2012.

47. Lu XY, Cao K, Li QY, Yuan ZC and Lu PS: The synergistic therapeutic effect of temozolomide and hyperbaric oxygen on glioma U251 cell lines is accompanied by alterations in vascular endothelial growth factor and multidrug resistance-associated protein-1 levels. J Int Med Res 40: 995-1004, 2012.
48. Dagistan Y, Karaca I, Bozkurt ER, Ozar E, Yagmurlu K, Toklu A and Bilir A: Combination hyperbaric oxygen and temozolomide therapy in C6 rat glioma model. Acta Cir Bras 27: 383-387, 2012.

49. Lu Z, Ma J, Liu B, Dai C, Xie T, Ma X, Li M, Dong J, Lan Q and Huang Q: Hyperbaric oxygen therapy sensitizes nimustine treatment for glioma in mice. Cancer Med 5: 3147-3155, 2016.

50. Beppu T, Kamada K, Nakamura R, Oikawa H, Takeda M, Fukuda T, Arai H, Ogasawara K and Ogawa A: A phase II study of radiotherapy after hyperbaric oxygenation combined with interferon-beta and nimustine hydrochloride to treat supratentorial malignant gliomas. J Neurooncol 61: 161-170, 2003.

51. Ogawa K, Yoshii Y, Inoue O, Toita T, Saito A, Kakinohana Y, Adachi G, Ishikawa Y, Kin S and Murayama S: Prospective trial of radiotherapy after hyperbaric oxygenation with chemotherapy for high-grade gliomas. Radiother Oncol 67: 63-67, 2003

52. Ogawa K, Yoshii Y, Inoue O, Toita T, Saito A, Kakinohana Y, Adachi G, Iraha S, Tamaki W, Sugimoto K, et al: Phase II trial of radiotherapy after hyperbaric oxygenation with chemotherapy for high-grade gliomas. Br J Cancer 95: 862-868, 2006.

53. Ogawa K, Ishiuchi S, Inoue O, Yoshii Y, Saito A, Watanabe T, Iraha S, Toita T, Kakinohana Y, Ariga T, et al: Phase II trial of radiotherapy after hyperbaric oxygenation with multiagent chemotherapy (procarbazine, nimustine, and vincristine) for high-grade gliomas: Long-term results. Int J Radiat Oncol Biol Phys 82: 732-738, 2012.

54. Yahara K, Ohguri T, Udono H, Yamamoto J, Tomura K, Onoda T, Imada H, Nishizawa S and Korogi Y: Radiotherapy using IMRT boosts after hyperbaric oxygen therapy with chemotherapy for glioblastoma. J Radiat Res 58: 351-356, 2017.

55. Zhou W, Dosey TL, Biechele T, Moon RT, Horwitz MS and Ruohola-Baker H: Assessment of hypoxia inducible factor levels in cancer cell lines upon hypoxic induction using a novel reporter construct. PLoS One 6: e27460, 2011.

56. Jones RB, Dorsett KA, Hjelmeland AB and Bellis SL: The ST6Gal-I sialyltransferase protects tumor cells against hypoxia by enhancing HIF-1 $\alpha$ signaling. J Biol Chem 293: 5659-5667, 2018.

57. Liu L, Ning X, Sun L, Zhang H, Shi Y, Guo C, Han S, Liu J, Sun S and Han Z: Hypoxia-inducible factor-1 alpha contributes to hypoxia-induced chemoresistance in gastric cancer. Cancer Sci 99: 121-128, 2008

58. Ambrosini G, Adida C and Altieri DC: A novel anti-apoptosis gene, survivin, expressed in cancer and lymphoma. Nat Med 3: 917-921, 1997.

59. Tamm I, Wang Y, Sausville E, Scudiero DA, Vigna N, Oltersdorf T and Reed JC: IAP-family protein Survivin inhibits caspase activity and apoptosis induced by Fas (CD95), Bax, caspases, and anticancer drugs. Cancer Res 58: 5315-5320, 1998.

60. Zhang SF, Zhang CW, Song YL, Zhang J and Xu JG: Prognostic role of survivin in patients with glioma. Medicine (Baltimore) 97: e0571, 2018.

61. Li JC, Han Y, Zhou D, Zhou Y, Ye M, Wang H and Du Z: Downregulation of Survivin gene expression affects ionizing radiation resistance of human T98 glioma cells. Cell Mol Neurobiol 38: 861-868, 2018

62. Joseph JV, Conroy S, Pavlov K, Sontakke P, Tomar T, Eggens-Meijer E, Balasubramaniyan V, Wagemakers $M$, den Dunnen WF and Kruyt FA: Hypoxia enhances migration and invasion in glioblastoma by promoting a mesenchymal shift mediated by the HIF1 $\alpha$-ZEB1 axis. Cancer Lett 359: 107-116, 2015

63. Mendichovszky I and Jackson A: Imaging hypoxia in gliomas. $\mathrm{Br}$ J Radiol 84 Spec No 2: S145-S158, 2011.

64. Rapisarda A, Uranchimeg B, Scudiero DA, Selby M, Sausville EA, Shoemaker RH and Melillo G: Identification of small molecule inhibitors of hypoxia-inducible factor 1 transcriptional activation pathway. Cancer Res 62: 4316-4324, 2002.

65. Kummar S, Raffeld M, Juwara L, Horneffer Y, Strassberger A, Allen D, Steinberg SM, Rapisarda A, Spencer SD, Figg WD, et al: Multihistology, target-driven pilot trial of oral topotecan as an inhibitor of hypoxia-inducible factor- $1 \alpha$ in advanced solid tumors. Clin Cancer Res 17: 5123-5131, 2011.

66. Stuhr LE, Raa A, Oyan AM, Kalland KH, Sakariassen PO, Petersen K, Bjerkvig R and Reed RK: Hyperoxia retards growth and induces apoptosis, changes in vascular density and gene expression in transplanted gliomas in nude rats. J Neurooncol 85: 191-202, 2007

67. Selvendiran K, Kuppusamy ML, Ahmed S, Bratasz A, Meenakshisundaram G, Rivera BK, Khan M and Kuppusamy P: Oxygenation inhibits ovarian tumor growth by downregulating STAT3 and cyclin-D1 expressions. Cancer Biol Ther 10: 386-390, 2010. 
68. Terraneo L, Virgili E, Caretti A, Bianciardi P and Samaja M: In vivo hyperoxia induces hypoxia-inducible factor-1alpha overexpression in $\mathrm{LNCaP}$ tumors without affecting the tumor growth rate. Int J Biochem Cell Biol 51: 65-74, 2014.

69. Storz P: Mitochondrial ROS-radical detoxification, mediated by protein kinase D. Trends Cell Biol 17: 13-18, 2007.

70. La Valle CR, George KM, Sharlow ER, Lazo JS, Wipf P and Wang QJ: Protein kinase D as a potential new target for cancer therapy. Biochim Biophys Acta 1806: 183-192, 2010.

71. Azoitei N, Kleger A, Schoo N, Thal DR, Brunner C, Pusapati GV, Filatova A, Genze F, Möller P, Acker T, et al: Protein kinase D2 is a novel regulator of glioblastoma growth and tumor formation. Neuro Oncol 13: 710-724, 2011.

72. Bernhart E, Damm S, Wintersperger A, DeVaney T, Zimmer A, Raynham T, Ireson C and Sattler W: Protein kinase D2 regulates migration and invasion of U87MG glioblastoma cells in vitro. Exp Cell Res 319: 2037-2048, 2013.

73. Fleegal MA, Hom S, Borg LK and Davis TP: Activation of PKC modulates blood-brain barrier endothelial cell permeability changes induced by hypoxia and posthypoxic reoxygenation. Am J Physiol Heart Circ Physiol 289: H2012-H2019, 2005.
74. Son JH, Cho YC, Sung IY, Kim IR, Park BS and Kim YD: Melatonin promotes osteoblast differentiation and mineralization of MC3T3-E1 cells under hypoxic conditions through activation of PKD/p38 pathways. J Pineal Res 57: 385-392, 2014.

75. Ha WH, Seong HS, Choi NR, Park BS and Kim YD: Recombinant human bone morphogenic protein-2 induces the differentiation and mineralization of osteoblastic cells under hypoxic conditions via activation of protein kinase D and p38 mitogen-activated protein kinase signaling pathways. Tissue Eng Regen Med 14: 433-441, 2017.

76. Gozal E, Roussel AL, Holt GA, Gozal L, Gozal YM, Torres JE and Gozal D: Protein kinase C modulation of ventilatory response to hypoxia in nucleus tractus solitarii of conscious rats. J Appl Physiol (1985) 84: 1982-1990, 1998.

(c) ()) $\Theta$ This work is licensed under a Creative Commons Attribution-NonCommercial-NoDerivatives 4.0 International (CC BY-NC-ND 4.0) License. 